ND) Nordic Council
of Ministers

\title{
CIRCULAR ECONOMY IN THE NORDIC CONSTRUCTION SECTOR
}

Identification and assessment of potential policy instruments that can accelerate a transition toward a circular economy 



\section{Circular economy in the Nordic construction sector}

Identification and assessment of potential policy instruments that can accelerate a transition toward a circular economy

Linda Høibye and Henrik Sand

TemaNord 2018:517 
Circular economy in the Nordic construction sector

Identification and assessment of potential policy instruments that can accelerate a transition toward a circular economy

Linda Høibye and Henrik Sand

ISBN 978-92-893-5488-2 (PRINT)

ISBN 978-92-893-5489-9 (PDF)

ISBN 978-92-893-5487-5 (EPUB)

http://dx.doi.org/10.6027/TN2018-517

TemaNord 2018:517

ISSN $0908-6692$

Standard: PDF/UA-1

ISO 14289-1

(c) Nordic Council of Ministers 2018

Cover photo: unsplash.com

Print: Rosendahls

Printed in Denmark

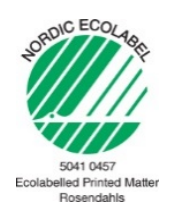

Disclaimer

This publication was funded by the Nordic Council of Ministers. However, the content does not necessarily reflect the Nordic Council of Ministers' views, opinions, attitudes or recommendations.

Rights and permissions

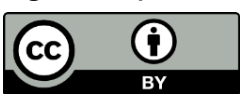

This work is made available under the Creative Commons Attribution 4.0 International license (CC BY 4.0) https://creativecommons.org/licenses/by/4.0

Translations: If you translate this work, please include the following disclaimer: This translation was not produced by the Nordic Council of Ministers and should not be construed as official. The Nordic Council of Ministers cannot be held responsible for the translation or any errors in it.

Adaptations: If you adapt this work, please include the following disclaimer along with the attribution: This is an adaptation of an original work by the Nordic Council of Ministers. Responsibility for the views and opinions expressed in the adaptation rests solely with its author(s). The views and opinions in this adaptation have not been approved by the Nordic Council of Ministers. 
Third-party content: The Nordic Council of Ministers does not necessarily own every single part of this work. The Nordic Council of Ministers cannot, therefore, guarantee that the reuse of third-party content does not infringe the copyright of the third party. If you wish to reuse any third-party content, you bear the risks associated with any such rights violations. You are responsible for determining whether there is a need to obtain permission for the use of third-party content, and if so, for obtaining the relevant permission from the copyright holder. Examples of third-party content may include, but are not limited to, tables, figures or images.

Photo rights (further permission required for reuse):

Any queries regarding rights and licences should be addressed to:

Nordic Council of Ministers/Publication Unit

Ved Stranden 18

DK-1061 Copenhagen K

Denmark

Phone +4533960200

pub@norden.org

\section{Nordic co-operation}

Nordic co-operation is one of the world's most extensive forms of regional collaboration, involving Denmark, Finland, Iceland, Norway, Sweden, and the Faroe Islands, Greenland and Åland.

Nordic co-operation has firm traditions in politics, economics and culture and plays an important role in European and international forums. The Nordic community strives for a strong Nordic Region in a strong Europe.

Nordic co-operation promotes regional interests and values in a global world. The values shared by the Nordic countries help make the region one of the most innovative and competitive in the world.

The Nordic Council of Ministers

Nordens Hus

Ved Stranden 18

DK-1061 Copenhagen K, Denmark

Tel.: +4533960200 www.norden.org

Download Nordic publications at www.norden.org/nordpub 



\section{Contents}

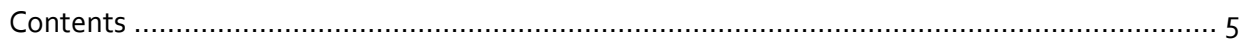

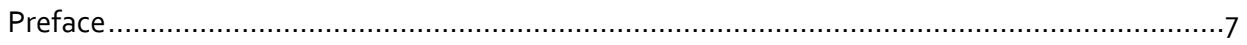

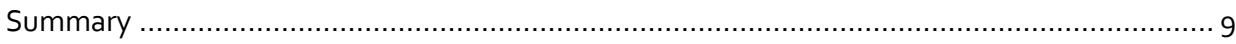

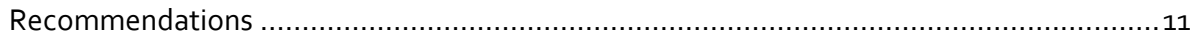

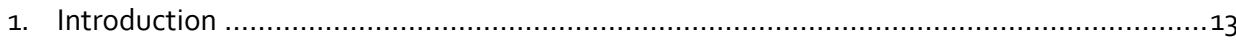

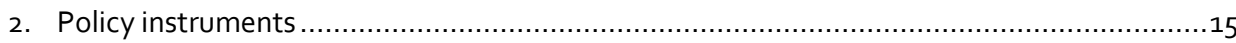

2.1 Content and quality of the building materials ...................................................

2.2 Use of reused building products and building products containing recycled resources

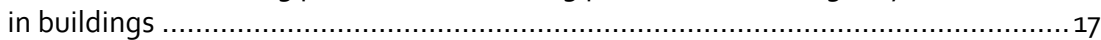

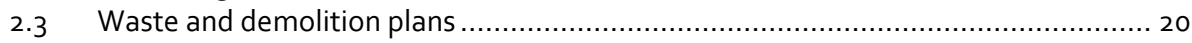

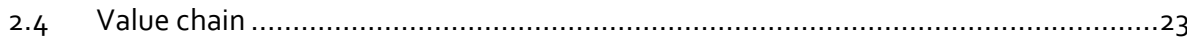

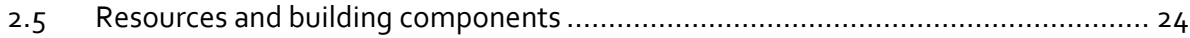

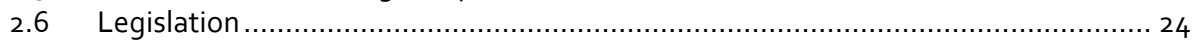

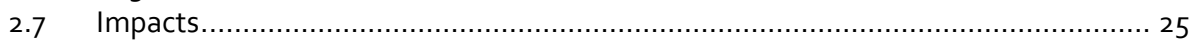

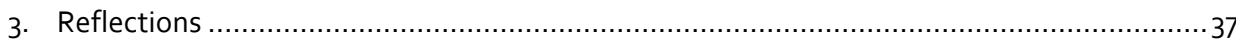

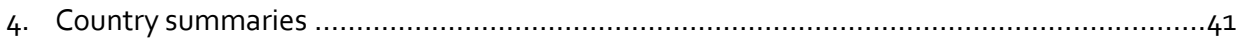

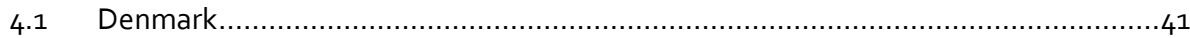

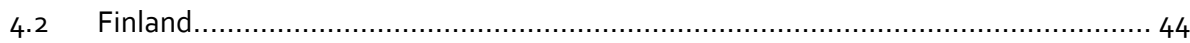

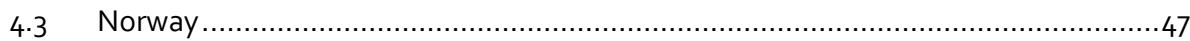

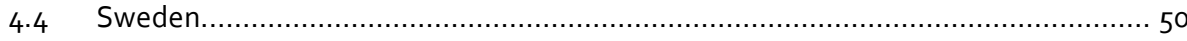

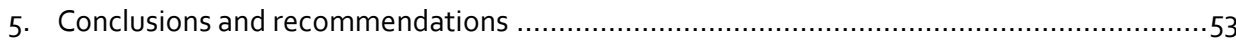

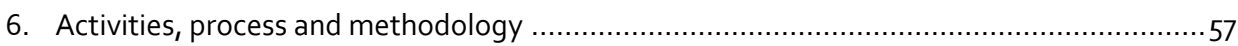

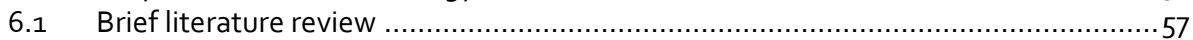

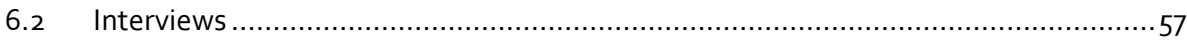

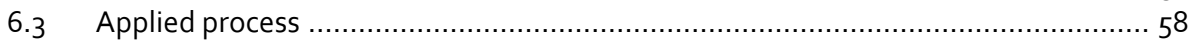

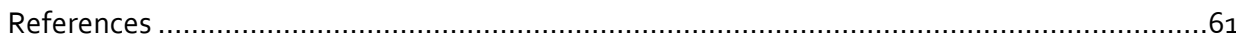

Names / organisations of interviewees and the interview dates ................................. 63

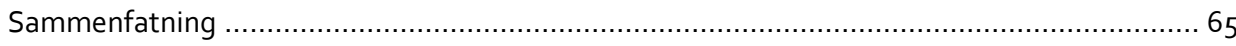

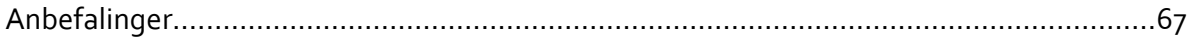





\section{Preface}

In recent years, environmental policy has become increasingly important for more efficient use of resources. This has led to increased focus on the development of a more circular economy. From an environmental-economic perspective, a circular economy means that the greatest possible prosperity is created at the lowest possible resource use and costs.

This applies at European level - in particular to the EU Commission's circular economy package to help European businesses and consumers to make the transition to a stronger and more circular economy where resources are used in a more sustainable way. ${ }^{1}$ And it also applies at national level to initiatives in the Nordic countries where the work includes all stages in the waste hierarchy; from prevention and waste reduction to reuse and recycling, recovery and disposal.

The Environment and Economics Group (MEG) under the Nordic Council of Ministers (NCM) has in recent years initiated a number of projects on the subject and has initiated projects on plastic waste, electronic waste and bio-waste. In this project, MEG shifts the focus to identify policy instruments that can promote resource efficiency and circular economy in the construction and demolition sector as inventories of waste in the Nordic countries show that the construction and demolition sector generates one of the highest volumes of waste in the $\mathrm{EU}^{2}$ and in all of the Nordic countries.

This report was funded by the Environment and Economy Group (MEG) and Nordic Waste Group (NAG) under the Nordic Council of Ministers (NCM) and prepared by COWI A/S and SYKE.

February 2018

\section{Signe Krarup,}

Chairman of MEG

\footnotetext{
${ }^{1}$ Quote in italic from https://ec.Europa.eu/commission/priorities/jobs-growth-and-investment/towards-circulareconomy_en

${ }^{2}$ http://ec.Europa.eu/growth/industry/sustainability/circular-economy/
} 



\section{Summary}

The purpose of this project is to identify and discuss potential policy instruments that can accelerate a transition toward a circular economy in the Nordic construction sector. ${ }^{3}$ Sixteen interviews were carried out with actors representing stakeholders from Denmark, Finland, Norway and Sweden.

The objective of a transition toward a circular economy in the construction sector is to maintain, reuse, refurbish and/or recycle resources and materials used in all parts of the value chain.

Most of the new policy instruments that the interviewees have suggested have focus on rules and regulation. Only a few of the interviewees focus on economic incentives, agreements or providing supplementary information. The suggested rules and regulations focus on product design and in particular design and demolition of buildings.

The policy instruments that the interviewees mainly suggest can be summarised in three main policy instruments:

1. Supplementary requirements for documentation of the content and quality of the building materials.

2. New requirements for documentation of the use of reused building products and building products containing recycled resources in buildings.

3. New requirements for waste and building demolition plans.

These policy instruments will require improved documentation of the technical performance (quality, durability, strength, content of hazardous substances etc.) of building materials, improved traceability of the building materials as well as minimum standards for recyclability and reuse of building materials.

The interviewees expect that the policy instruments will have the most direct impact for the building material producers and especially the building owners who will need to reflect such requirements in the sourcing of building materials and in the design, refurbishment and demolition of buildings.

The interviewees mostly suggest anchoring the requirements in the building regulation in Denmark, Finland, Norway and Sweden and secondly in:

- Environmental Product Declarations (EPD).

- Construction Products Regulation (CPR).

3 Including demolition of buildings. 
- Building Information Modelling System (BIM).

- Material and/or building passports.

Across the suggested policy instruments, the interviewees find that the suggested policy instruments will have great positive environmental impacts, neutral budgetary impacts for public authorities and positive financial impacts for private companies.

These impact expectations mainly apply to the three summarised policy instruments.

Most of the interviewees expect an implementation phase where companies have to adapt to the new rules and regulations. This may imply a short run implementation costs, but in the long run, the interviewees expect that impacts - and especially the environmental impacts - to be significantly positive.

The positive impacts are expected by the interviewees to occur due to the resultant savings in resource consumption when more building materials are reused and recycled, and thus fewer produced using new primary resources. In the long run, these positive impacts are expected to offset the negative impact that may be created in the implementation phase caused by a possibly increased need for logistics, storage and transportation of recycling or reusing building materials.

The interviewees expect that the resource consumption can be reduced by approximately $20 \%$ compared to the current consumption of building materials in the buildings and construction sector today.

A reduction of $20 \%$ in resource consumption results in a decrease of greenhouse gas emissions by approximately 10 million tonnes in total for all four Nordic countries in all parts of the value chain from the extraction of raw materials, transportation and the manufacturing phase of the building materials.

The budgetary impacts for public authorities are not estimated as the interviewees view it as neutral; meaning that the administrative costs and expected changes in tax revenues of the suggested policy instruments are viewed as insignificant - in both the long and short run.

The financial impacts for the private companies are viewed positively by the interviewees, and a $1.7 \%$ annual growth in the long run in the total gross profit equals a net present (2018) impact of 803 million EUR in the first year (2023) after a full implementation of the policy instruments that the interviewees suggest.

Implementation of the 32 policy instruments that the 16 interviewees suggest is expected to speed up the transition toward a circular economy. But the implementation of the policy instruments can be complicated and the implementation process needs to address a number of barriers that may hinder a reduction in the use of resources, greenhouse gas emissions and a full growth in gross profit.

According to COWI the main barriers are currently:

- lack of (early stage) value chain corporation and partnerships in the construction secto

- lack of economy of scale 
- lack of quality assurance marking schemes of reused building materials

- content of hazardous substances in existing building products currently embedded in buildings.

From the perspective of policy makers, COWI expect that new rules and regulations cannot stand alone - neither for overcoming the above-mentioned barriers nor as the only policy instruments for accelerating a transition toward a circular economy in the Nordic construction sector.

COWI expects that companies may need stronger economic incentives to change their existing and often linear business approach. New taxation structures, fees and financial support through public programmes such as innovation and demonstration schemes can create such incentives.

New taxation structures and fees will lower the price on recycled and reused building materials and increase the market demand (a market push for recycled materials). A different taxation structure and fees on specific building materials may though be complicated and costly to develop and enforce.

Furthermore, a lower tax on recycled and reused building materials will lead to a lower tax revenue that are expected to grow as the demand for recycled and reused materials increases. The costs of new taxation structures and fees therefore may need to be time limited and phased out as the market for recycled and reused building materials grows and becomes efficient and competitive to non-recycled and nonreused building materials.

If so, a combination of new rules, regulation and stronger economic incentives can give public authorities a key role in accelerating a transition toward a circular economy in the construction sector. Furthermore, the actions can also create a large-scale demand of building designs based on circular business approaches and facilitate the needed dialogues, partnerships and processes.

\section{Recommendations}

To support the implementation of policy instruments that can accelerate a transition toward a circular economy in the Nordic construction sector COWI recommends The Environment and Economic Group (MEG) and Nordic Waste Group (NAG) under the Nordic Council of Ministers (NCM) to:

- Analyse how the suggested policy instruments apply to the legislative structure and policies of Denmark, Finland, Norway and Sweden, respectively. This includes prioritising the suggested policy instruments most suitable for implementation in each country.

- Develop a socio-economic impact analysis of the suggested policy instruments by collecting and analysing national specific data and include key stakeholders from the value chain for input and validation. 
- Investigate the definitions of recycled and reused building materials from the construction sector to ensure that the assessments are performed on the same assumptions and decisions within and also among each of the Nordic countries.

- Collect information about supplementary environmental impact categories such as embodied energy, use of scarce and renewable resources, acidification etc. to ensure an environmental impact assessment based on a more holistic approach.

- Collect and disseminate information and data on best-case examples of value chain collaboration and quality assurance mechanisms as inspiration for the Nordic construction sector and policy makers.

- Design national roadmaps by inviting large private and public builders owners to workshops and/or dialogues about the benefits and barriers for a transition toward a circular economy, including the most needed actions to succeed. NAG or MEG can facilitate the workshops and share key findings.

- Facilitate increased collaboration between the Nordic countries to realize the expected positive gains from the circular economy transition. Examples are crosscycle and cross-sector collaboration which can be improved among industries. Other examples are increased collaboration between national policy makers with the aim of decreasing transactional costs, leverage potential complementarities etc. 


\section{Introduction}

In Denmark, the construction sector generates almost 36\% of the 11.3 Mtonnes of yearly waste. 4 In Sweden, the sector accounts for approximately $30 \%$ of the total 27 Mtonne yearly waste and is by far the largest waste source. ${ }^{5}$ In Norway ${ }^{6}$ and Finland, 7 the picture is the same; the construction sector accounts for a significant part of the generated waste. In this report the demolition of buildings are included in the term "construction sector".

Waste from construction and demolition activities is often used as a substitute for gravel. Thus resulting in a high percentage of recycled waste. It can be argued that waste used in this manner is down-cycled leading to a significant loss of material value.

Waste from construction and demolition may contain hazardous substances that need to be identified and removed from the building materials to allow for possible recycling purposes thus ensuring that the hazardous substances are removed from the recycling loop - thus preventing health and environmental problems in new product system loops.

The purpose of the project is to create a guiding perspective for policy makers by identifying and discussing policy instruments that can accelerate a transition toward a circular economy in the construction sector in Denmark, Finland, Norway and Sweden. This includes identifying barriers that may exist in current legislation in relation to the identified policy instruments.

This project focuses on policy instruments as regulatory tools used by public authorities and can be divided into the following categories:

- Economic incentives (grants and taxes).

- Rules and regulation (prohibition, injunction, permitting, inspecting, monitoring).

- Agreements (goals and intents).

- Information.

The policy instruments are identified by interviewing 16 interviewees from Nordic organisations and authorities that have special insight into policy instruments, resource efficiency, circular economy and the construction sector.

\footnotetext{
4 "Danmark uden Affald"(page 19) - http://mst.dk/media/mst/Attachments/Ressourcestrategi_DK_web.pdf 5 In Sweden, subtracting the waste created from extraction of minerals as the biggest fraction, highlights construction waste as the key waste source (p8): http://www.naturvardsverket.se/Documents/publikationer6400/978-91-620-66192.pdf?pid=13196

${ }^{6}$ Avfallsregnskap for Norge, avfallsmengder etter kilde: https://www.ssb.no/natur-og-miljo/statistikker/avfregno/aar/201506-16

7 "Towards a recycling society - The National Waste Plan for 2016"(page 33)

https://helda.helsinki.fi/bitstream/handle/10138/38022/FE_14_2009.pdf?sequence=1
} 
The interviewees from Denmark, Norway and Sweden was suggested by COWI and for Finland by SYKE. The MEG and NAG steering group gave input and approved an updated list of interviewees that COWI and SYKE have conducted interviews with.

The 16 interviewees all have special insight into policy instruments, resource efficiency, circular economy and market mechanisms in the construction sector. They represent a variety of stakeholders from branch organisations to governmental bodies. COWI has not suggested individual companies as this project focus on policy instruments - not on specific building products or materials.

The interviewees have identified the policy instruments that they find are needed the most to accelerate a transition toward a circular economy in the construction sector in Denmark, Finland, Norway and Sweden. The suggested policy instruments can be a change in an existing policy instrument or it can be a policy instrument that is not currently in use.

The interviewees were asked to specify which type of resources, which building components, which part of the value chain and which legislation their suggested policy instrument targets. Lastly, they were asked to quantify the expected impact.

COWI, which has conducted the analysis together with SYKE, has made an overall impact estimations primarily based in the responses obtained during the interviews, a brief literature review of relevant publications/reports and an additional assessment of the suggested policy instruments. 


\section{Policy instruments}

Sixteen interviews have been conducted with interviewees - four interviews in Denmark, Finland, Norway and Finland, respectively. Each of the interviewees has suggested two policy instruments that they consider the most necessary to accelerate a transition toward a circular economy in the construction sector in their country. In total, the interviewees have suggested 32 policy instruments.

Of the 32 policy instruments proposed, the majority focus on new rules and regulations. Few focus on the need for new economic incentives, new agreements or providing new information. This is reflected in table 1 below.

Table 1: Types of policy instrument

$\begin{array}{lrrrr}\text { Country } & \text { Economic incentives } & \text { Rules and regulation } & \text { Agreements } & \text { Information } \\ \text { Denmark } & 2 & 5 & 1 & (1) \\ \text { Finland } & 0 & 7 & 0 & 1 \\ \text { Norway } & 0 & 7 & 0 & 1 \\ \text { Sweden } & (1) & 5 & 0 & 3+(1)\end{array}$

The parenthesis in Table 1 shows a type of policy instrument that has been mentioned as an add-on or supplement to rules and regulation as the main policy instrument.

The new rules and regulation that the interviewees mainly suggest can be summarised into three main policy instruments:

1. Requirements for documentation of the content ${ }^{8}$ and quality of the building materials.

2. Requirements for the documentation of the use of reused building products and building products containing recycled resources in buildings.

3. Requirements for waste and demolition plans.

These policy instruments will require improved documentation of the technical performance (quality, durability, strength etc.), content of hazardous substances etc. of building products, improved traceability of the content of building materials as well as minimum standards for recyclability and reuse of building materials.

Such documentation, traceability and minimum requirements will (according to the interviewees) affect the whole value chain for buildings. It will also have the most direct impacts for the building material producers and especially the building owners

\footnotetext{
${ }^{8}$ E.g. hazardous substances, secondary materials etc.
} 
who will need to reflect such requirements in the sourcing of building materials and in the design, refurbishment and demolition of buildings.

The interviewees expect the three summarised groups of policy instruments to accelerate the transition toward a circular economy in the construction sector as they expect that the requirements will create a market pull when the building owners starts sourcing product and services that improves the recyclability and reuse of building materials.

For Finland, there is also a focus on simplifying and streamlining chemical and waste regulations and regulatory procedure ${ }^{9}$ through a system based on end-of-waste criteria and standards as the current system is based on a case-by-case decisions which are considered inefficient by the Finnish interviewees.

In the following, the policy instruments that the interviewees have suggested are listed. The policy instruments are grouped according to three summarised groups of policy instruments.

The full description of all of the suggested policy instruments can be found in the fact sheets in the appendix III to this report.

\subsection{Content and quality of the building materials}

The interviewees who suggest requirements for documentation of the content and quality of the building materials focus on the technical performance, the recycling rate, the traceability of the building materials and on sharing this information in a database. One stakeholder also focus on lower VAT on building product containing recycled materials and reused building products.

The policy instruments that the interviewees suggest are:

- Requirements for the technical performance and quality of reused and recycled products. (Denmark). A declaration of the technical performance (quality, durability, strength, content of hazardous substances etc.) can be incorporated into the building regulation to ensure the quality level of buildings. Impact: There are opportunities to reuse building materials and recycle resources in new building products - but certification/verification is needed to minimize the risk of buildings with decreased quality and life time. Interviewees: Elly Kjems Hove and Jakob Orbesen from the Confederation of Danish Industry.

- Require a certain content (\%) of recycled resources in new products in the national building regulation (Norway). The policy instrument will enable a pull from the market when the designers/architects can prescribe the use of recycled resources in new building products through a revised building regulation. Impact: The policy instrument leads to increased sales and higher profits for the producers of

\footnotetext{
9 This is the main focus of the MASA and MARA Acts which concerns the management of waste from earth constructions (which include roads and railways) and intend to reduce the regulatory burden of environmental permit procedures. For further information, please see fact sheets from Finland in the appendix to this report.
} 
building products due to larger market pull and reduced costs of resources. Interviewee: Rannveig Ravnanger Landet, the Federation of Norwegian Construction Industries.

- Traceability for building materials/products (Norway). The requirement can be introduced through stricter requirements for the content of information about EoL (end-of-life) in the Environmental Product Declarations. The traceability for building products can also be incorporated as supplementary information in the Building Information Modelling System (BIM), which is widely used by engineers. Impact: It is assessed that the building owners can gain financial benefits from a selective demolition and subsequent reuse of building materials and recycling of resources after the building has been demolished. Interviewee: Jan Eldegaard, Bygg uten Grenser.

- Information and guideline system/database on material contents (Sweden). The improvement of information and guideline system/database about the content (share of primary and secondary materials plus the potential content of hazardous substances) of materials in building products can be leveraged by revising a set of informative policy instruments. The public sector is not included. Impact: It is estimated that the proposed changes will result in significant reductions in environmental impacts due to increased knowledge, identification and substitution of hazardous materials and chemicals, reduced use of primary resources and economic gains. The costs are expected to decrease along the entire value chain. Interviewee: Marianne Hedberg, The Swedish Construction Federation

One stakeholder proposed an economic incentive to increase the recycled content in building materials by suggesting:

- Lower or no VAT on building materials that are based on the principles of Circular Economy (Denmark). Lower or no VAT on building materials that are based on the principles of Circular Economy should be incorporated into the national VAT system. Impact: A lower VAT on building products with recycled resources and reused building products will result in a lower VAT revenue on building products, but will also result in a market pull effect. Interviewee: Jacob Hartvig Simonsen, The Danish Waste Association.

\subsection{Use of reused building products and building products containing recycled resources in buildings}

The interviewees who suggest documentation of the use of reused building products and building products containing recycled resources focus on setting minimum requirements, green resource efficient criteria and quota for the share of reused building products and building products containing recycled resources in buildings. 
Information about the selected building products in buildings are suggested to be documented in "building passport"and one stakeholder also suggest giving the municipal building owners strong financial incentives to source reused and recycled building materials.

The policy instruments that the interviewees suggest are:

- New green criteria with focus on increased quality of recycling, increased use of building products with recycled resources and increased reuse of building products in the national building regulation (Denmark). At the beginning, the proposed policy instrument will act as a green obligatory supplement to the national building regulation before becoming mandatory (similarly to the incorporation of the Danish energy classes). This may include requirements for a "building passport". Impact: Circular building regulations are expected to increase resource efficiency throughout the life time of the building. The extent and value of reuse and recycling of building materials over time due to increased resource efficiency. In addition, it is expected to accelerate the phasing out of hazardous substances and improve the quality of materials, as well as focus on the life time of building materials, energy consumption and $\mathrm{CO}_{2}$ load arising during production of building materials. A building passport is expected to provide a better and cheaper starting point for selective demolition, avoiding costs required to investigate and map out building products containing hazardous substances prior to demolition. This would allow increased revenue and reduced costs associated with general handling and resale of building materials.

It is also expected that the policy instrument entails increased costs for the building owner in the planning phase (transition to streamlined planning). The increased costs can be offset in the demolition phase as the value of the recycled and reused materials are increased. Interviewee: Niels Bukholt, the Department of Circular Economy \& Waste in the Danish Environmental Protection Agency.

- Motivation of and/or setting (minimum) requirements to support the principles of Circular Economy (Denmark). It can include requirements on the use of building products without hazardous substances as well as a focus on Design for Disassembly - Repair - Maintenance. Minimum requirements can be incorporated in the national building regulation for reuse/recycling of building materials from renovation/demolition in combination with special focus on especially the use of secondary materials through voluntary systems (e.g. certification schemes), a revised tax structure of waste and requirements on documentation and traceability. Impact: increased costs for the building owner in the planning phase. The increased costs can be offset in the demolition phase as the values of the recycled resources and reused products are increased. Interviewee: Anke Oberender, Managing Director at the Centre for Management and Recycling of Construction Waste in Denmark.

- Resource efficiency criteria for renovation and construction (Finland). Criteria could include quotas for recycled content in building materials, and/or standards related 
to the recyclability of building materials. Clear instructions for calculations are required to be developed and implemented. Minimum level for criteria could be national, obligatory and set quite low. However, they could also be set higher through municipal regulations. Requiring that such criteria are met through regulation would give clear and simple instructions and set a minimum level for the material efficiency in all construction and renovation processes. Impact: Costs to public authorities associated with the development and implementation of such certification scheme. This instrument could have a wide impact, but would need to be developed in line with existing and planned regulations. Disagreement about e.g. which materials are the most efficient can slow down the process of making such wide regulations. Interviewee: Nea Metsänranta, Circular Economy Expert, Helsinki Region Environmental Services Authority in Finland.

- Stricter documentation requirements for all materials used for new buildings (Norway) - for example by using the same model or scheme as for instance BREEAM. This includes registering the chemical substances and all building products used in the building. The documentation should follow the building owner as a "building passport"and be supplemented/amended when the building is renovated or changes to the building are made. Impact: Increased building design and construction costs, but rent of certified buildings, demolition costs, insurance costs and sale of reused and recyclable building materials may lower the costs for the building owner. Interviewees: Sverre Huuse Fagerlie, Head of department waste recycling and treatment in Machine Contractors' Association in Norway (MEF), and: Rannveig Ravnanger Landet, director of Environment and Energy in The Federation of Norwegian Construction Industries (BNL).

- Quota on the use of recycled resources and reusable building products in constructions (Sweden). It will make substantial contributions when developing the market for recycled and reusable materials and products in the construction sector. The intention is to put demands on the use of recycled and reusable materials in construction to increase the percentage of recycled resources instead of using the materials for energy production and landfill. The intention is also to increase the level of policy initiatives associated with the [Swedish] 70\%-goal, which currently lacks a stringent connection to policy instruments that can be used to achieve the goal. The policy change could be entered into the Planning and Building Act or the Environmental Code. Impact: The key benefit is to increase the market demand for recycled resources and reused building products, which affects the whole value chain. The trade-off is that economic instruments are preferable in general; however, this legislative policy instrument would be very effective under the current circumstances. Additionally, the instrument would strongly benefit from better statistical knowledge of resource flows, which is a key barrier to system understanding and improvements today. Stimulating more recycled and reusable materials and products can improve the price dynamics on this market. Interviewee: Britt Sahleström, CEO of The Swedish Recycling Industries' Association. 
In addition to the above suggestions for new rules and regulation, an interviewed stakeholder also suggests a policy instrument to create new economic incentives through dispensation from the capital cost ceiling for the Danish municipalities.

This stakeholder suggested dispensation from the ceiling of the capital cost ("anlægsloftet") for the Danish municipalities for construction that are based on the principles of Circular Economy (Denmark). For example: use of $20 \%$ reused/recycled materials in new buildings. Impact: Dispensations will create a significant demand for building designs and products based on the principles of Circular Economy. This will support the creation of a market for secondary raw materials and reused building products. The policy instrument entails a need to verify the quality and performance of the recycled resources and reused building products - e.g. by using CE marking, ETV schemes etc. Requirements to the content of hazardous substances must be incorporated into the verification. Interviewee: Jacob Hartvig Simonsen, CEO at the Danish Waste Association.

\subsection{Waste and demolition plans}

The interviewees who suggest requirements for waste and demolition plans focus on screening, mapping and sorting valuable building products for reuse and recyclable resources and on setting minimum recycling rates and end-of-waste criteria and on providing guidelines and training for demolition companies.

The policy instruments that the interviewees suggest are:

- Demand/requirement for the development of a demolition plan (Denmark). This includes focus on higher quality of reuse and recycled materials, removal of hazardous substances, information about reusable, recyclable and contaminated materials, better supervision and training, and certifying employees at demolition companies. Impact: Requirements for development of a demolition plan prior to demolition may ensure increased reuse and recycling of building materials at a higher value. The costs for the building owner will rise as the price for demolition will increase due to the time spent for the development of a demolition plan. The financial gains from the sale of resources are expected to rise. Interviewee: Niels Bukholt, the department of Circular Economy \& Waste in The Danish Environmental Protection Agency.

- Screening (and mapping) of the building materials (Denmark). The requirements for screening (and mapping) of the building materials can be incorporated into the national building and waste legislation. The screening (and mapping) can also be introduced via certification schemes and increased information about hazardous substances in building materials. Impact: The municipalities need to spend more time on inspection and supervision of demolition projects, which entails increased costs to the municipalities. Furthermore, the building owner may have increased costs for selective deconstruction as compared with demolition - but with the possibility of financial benefits from the sale of the building materials which can 
be reused or recycled. Lastly, the policy instrument can provide larger incentives for increased cooperation throughout the value chain. Interviewee: Anke Oberender, Managing Director at the Centre for Management and Recycling of Construction Waste in Denmark.

- End-of-waste criteria (Finland). The proposed policy instrument involve the waste from earthworks, which are in the process of being amended through the MARA ${ }^{10}$ and MASA ${ }^{11}$ act. The purpose of the MARA act is to reduce the regulatory burden of waste permitting. The goal is that construction waste materials must have common environmental criteria and to allow certain waste fractions to be recycled without having to apply for an environmental permit on a case-by-case basis. Thus making it easier to recycle materials. The purpose of the MASA act is to reduce the regulatory burden of waste permitting. The goal is that soil waste materials would have common environmental criterion - and also to allow certain waste fractions to be recycled without having to apply for an environmental permit on a case-by-case basis, thus making it easier to recycle materials. Impact: The MASA and MARA Acts have the potential to reduce regulatory burdens, increase recycling, reduce the time for waste processing, decrease transportation, reduce costs and storage space, improve the possibilities of developing new businesses and increase innovation. Interviewee: Pekka Vuorinen, Confederation of Finnish Construction Industries.

- Increase the recycling rate demand from buildings and construction waste (Norway). An increase in the recycling rate can be obtained by stricter recycling goals in the waste legislation. Increased recycling should also be reflected in the building regulation by requirements for the use of building products containing secondary resources. Impact: The impacts are related to increased use of secondary resources, which lowers the environmental impacts by using less primary resources and thus also reduced emission of greenhouse gasses. It is expected that this involves increased costs to the building owners as documentation of the requirement involves man hours (which equals increased costs). Interviewee: Gunnar Grini, the Federation of Norwegian Industries.

- Expanding the requirement for a waste plan for the demolition of all buildings bigger than $100 \mathrm{~m}^{2}$ (Norway). This policy instrument can be embedded into the national building regulation. To ensure the full effect of the policy instrument, the requirement must be mandatory. Impact: The expected impacts are increased costs for the building owner when dismantling and demolishing the building. Furthermore, it is expected that the municipalities need to spend more time on supervision of waste plans and demolitions. Lastly, it is expected that there will be positive environmental impacts in the long term due to reduced amounts of waste plus more recycling and reuse. Interviewee: Gunnar Grini, the Federation of Norwegian Industries.

\footnotetext{
${ }^{10}$ Government Decree 591/2006 concerning the recovery of certain wastes in earthworks.

${ }^{11}$ Government Decree concerning the recovery of certain soil waste in earth construction (currently being developed).
} 
- Waste plan, environmental management description and sorting requirements in all new buildings (Norway). The proposed policy instrument must be embedded into the building legislation by incorporating additional mandatory requirements. To ensure compliance, the authorities must verify that the requirements are complied with - thus increased supervision is needed. Impact: The proposed changes are expected to lead to more paperwork and bureaucracy. It is also expected that there will be a transition period in which especially small and medium-sized actors have to adjust to the new regulations while the municipality as building agency must employ more people to cope with the increased workload. The proposed policy instrument will also increase the responsibility of the building owners and medium and small-scale construction companies. Interviewee: Sverre Huuse Fagerlie, the Norwegian Association of Heavy Equipment Contractors.

- Resource and waste guidelines for demolitions, incl. audits, waste management and procurement of demolition contractors (Sweden). It is recommended that the proposed changes are obtained through guidelines on: 1) Audits/identification ahead of demolition as well as procurement of audits, 2) Reuse, sorting and waste management as well as procurement of demolition contractor, and lastly 3 ) Sorting and waste management as well as procurement of construction contractors. Impact: It is expected that there are several positive gains to be achieved. Resource and waste guidelines can provide demolition contractors an improved understanding and categorisation of materials and their environmental impact, which to a high degree determines the opportunities for recycling and reuse. Thus, the benefits largely lies in the fact that the guidelines and agreements reduce knowledge asymmetries and therefore increase the share of the sector that acts in a "correct"way (as per the definition in this project) due to the information and knowledge sharing in itself and also due to harmonisation of different aspects that provide a more well-functioning market. Also resource efficiency can reduce costs along the value chain. Interviewee: Marianne Hedberg, The Swedish Construction Federation.

- Improve the responsibilities of contractors to sort recyclable resources and reusable building products (Sweden). This concerns a suggestion for a new public regulatory policy instrument that improves the responsibilities of contractors to actively sort recyclable resources and reusable building products. The policy change would affect the whole sector and value chains as a systems perspective including all stakeholders in the value chains. The policy change could be entered into the Environmental Code or the Waste Ordinance. Impact: The intention is to improve the recycling and reuse market through more homogenous fractions and to increase the level of policy initiatives associated with the $70 \%$-recycling goal in Sweden, which currently lacks a stringent connection to policy instruments that can be used to achieve the goal. Interviewee: Britt Sahleström, the Swedish Recycling Industries' Association. 


\subsection{Value chain}

In this project, the value chain of the building and construction sector consists of:
A. Product design (including choice of raw materials for the products).
B. Design of building.
C. Production process (construction).
D. Consumption/use (operation and maintenance).
E. Refurbishment (renovation).
F. From waste to resources (demolition).
G. nnovation, investment and other cross-cutting issues.

This is shown in the table below and reflects which part of the value chain the interviewees find the most relevant for policy makers to focus on that has the greatest effect to most parts of the value chain.

The underlying assumption is that the building owner and developers who finance the building set the criteria for the design and demolition of buildings. They hereby have a key role in initiating a transition toward a more circular economy in the building and construction sector.

Table 2: The policy instrument according to the value chain

\begin{tabular}{|c|c|c|c|c|c|c|c|}
\hline Country & A & B & c & D & E & $F$ & G \\
\hline Denmark & 2 & 3 & & & (4) & 3 & \\
\hline Finland & 1 & 1 & & & (1) & 6 & \\
\hline Norway & 2 & 4 & & & (4) & 1 & 1 \\
\hline Sweden & 1 & 1 & & & (1) & 5 & \\
\hline
\end{tabular}

The parenthesis in Table 2 indicates that the interviewees find $b$ ) Design of building and e) Refurbishment (renovation) closely related as refurbishment is viewed as a re-design of buildings.

In relation to the value chain of the construction sector, the suggested rules and regulations focus on product design and especially the design and demolition of buildings.

The construction (c) and use phase (d) were not mentioned by any of the interviewees. This is remarkable as there has been great focus on the use phase in recent years in the Nordic countries - primarily concerning energy. Also, as we expect that building users will demand a higher degree of flexibility and liveability and thereby further accelerate a transition toward a more circular based economy. In other projects it was estimated that the waste production from the construction phase is $10-15 \%$ of the acquired building products for building project. COWl estimates that there is also a potential for environmental and economic gains in these two phases of the value chain. 
As the interviewee did not focus on these phases, the potential gains of improving the circular economy in these phases are not assessed in this project.

\subsection{Resources and building components}

The policy instruments that the interviewees most often suggest relate to all types of resources and building components. For Denmark, Norway and Sweden, the policy instruments that the interviewees suggest focus on the use of concrete, tiles, bricks and masonry, wood and insulation material. The Finnish interviewees state that wood is a key resource in the construction sector in Finland. ${ }^{12}$

Concerning the building components the interviewees focus on the facade, the foundation, the windows and the insulation.

\subsection{Legislation}

The interviewees mostly suggest anchoring the requirements in the building regulation in Denmark, Finland, Norway and Sweden, respectively, and secondly in:

- Environmental Product Declarations (EPD, which "is an independently verified and registered document that communicates transparent and comparable information about the life-cycle environmental impact of products"). ${ }^{13}$

- Construction Products Regulation (CPR, which "lays down harmonised rules for the marketing of construction products in the EU. The Regulation provides a common technical language to assess the performance of construction products"). ${ }^{14}$

- Building Information Modelling System (BIM, which is "a process involving the generation and management of digital representations of physical and functional characteristics of places" 15 and which can be used through a project life cycle in for example construction management and facility operation).

- Material passports which is a "document consisting of all the materials that are included in a product or construction. It consists of a set of data describing defined characteristics of materials in products, which give them value for recovery, recycling and re-use".$^{16}$ The material passports can be encapsulated in a logbook (also called a building passport).

\footnotetext{
${ }^{12}$ Petrus Kautto from the Finnish Environmental Institute highlight that $90 \%$ of the detached housing building stock is wood constructions, and that there is a current growth of multi-storey wooden buildings. He also finds that there is currently "no significant potential to reuse modular wooden elements'.

${ }_{13}$ See http://www.environdec.com/en/What-is-an-EPD/

${ }_{14}$ See https://ec.europa.eu/growth/sectors/construction/product-regulation_da

${ }_{15}$ See https://en.wikipedia.org/wiki/Building_information_modeling

${ }^{16}$ See https://en.wikipedia.org/wiki/Material_passport
} 
The interviewees do not indicate that the logistics or environmental legislation are significant obstacles for a transition toward a circular economy in the construction sector. Nor do they identify specific economic incentives (such as taxation and fees) as important for policy makers to focus on in this context.

\subsection{Impacts}

The interviewees were asked to estimate the impacts of the policy instruments on six types of impacts:

1. Environment and resources, which includes the amount of resources and the greenhouse gas emissions.

2. Budgetary impacts for public authorities, which mainly concerns change in the revenue from taxation and change in administrative costs.

3. Financial impacts for the private companies, which mainly concerns change in turnover for the affected (group of) companies, including taxation and administration.

4. Export of goods and thus also the competiveness of the companies in the Nordic countries.

5. Export of knowledge concerning circular economy, new technical solutions etc.

6. Benefits generated due to a higher degree of collaboration between the Nordic countries to a transition to increased circular economy.

The interviewees have estimated the six types of impacts on a scale of -5 to +5 where 5 is a very negative impact (such as a significant increase in the greenhouse gas emission or decrease in the turnover for private companies), o (zero) is a neutral impact and +5 is a very high positive effect (such as a significant decrease in the consumption of primary resources or increase in gross profit for private companies).

Table 3 shows the average score for and across Denmark, Finland, Norway and Sweden.

Table 3: The rating of the main impacts

\begin{tabular}{lr|rr|r|r|r} 
Country & $\begin{array}{r}\text { Environment } \\
\text { impacts }\end{array}$ & $\begin{array}{r}\text { 2: Budgetary } \\
\text { impacts for } \\
\text { public } \\
\text { authorities }\end{array}$ & $\begin{array}{r}\text { 3: Financial } \\
\text { impact for } \\
\text { private } \\
\text { companies }\end{array}$ & $\begin{array}{r}\text { 4: Export of } \\
\text { goods and thus } \\
\text { also } \\
\text { competiveness }\end{array}$ & $\begin{array}{r}\text { 5: Export of } \\
\text { know- } \\
\text { ledge }\end{array}$ & $\begin{array}{r}\text { 6: Benefits generated } \\
\text { due to a higher } \\
\text { degree of } \\
\text { collaboration }\end{array}$ \\
\hline Denmark & 2.2 & -0.9 & 1.7 & & & \\
Finland & 3.0 & 1.9 & 2.2 & 0.3 & 1.9 & 1.4 \\
Norway & 2.7 & -0.1 & 1.1 & 0.6 & 0.8 & 0.4 \\
Sweden & 3.9 & 0.8 & 2.3 & 0.1 & 3.5 & 1.0 \\
Average & 2.9 & 0.5 & 1.8 & 0.6 & 2.1 & 1.5 \\
\hline
\end{tabular}


Across the suggested policy instruments, the interviewees find that the suggested policy instruments will have great positive environmental impacts, neutral budgetary impacts for public authorities and positive financial impacts for private companies.

The interviewees also find that their suggested policy instruments can have positive impacts on the export of knowledge concerning circular economy, new technical solutions and sustainable building materials etc. It is also expected that there will be benefits due to a higher degree of collaboration between the Nordic countries.

The impact from the export of products and Nordic collaboration is viewed as almost neutral.

These impact expectations also apply to the three summarised policy instruments (mentioned at page 4):

1. Requirements for documentation of the content ${ }^{17}$ and quality of the building materials.

2. Requirements for the documentation of the use of reused building products and building products containing recycled resources in buildings.

3. Requirements for waste and demolition plans.

Especially the Finnish and Swedish interviewees expect that the policy instruments focusing on requirements for the documentation of the use of reused building products and building products containing recycled resources in buildings will have the most positive impact on the environment (lower greenhouse gas emissions and consumption of primary resources) and the financial impacts on private companies (higher turnover and gross profit).

Most of the interviewees expect a transition phase where companies have to adapt to the new rules and regulations. This may imply a short run cost for some companies, but in the long run, the interviewees expect the impacts to be significantly positive especially for the environmental impacts.

According to the interviewees, the positive impact on the environment and the financial impact for private companies occur mainly due to savings in resources when an increased share of high value building products are being reused and resources are recycled.

In this analysis COWI defines

- Short run as 2-5 years from implementation of the suggested policy instruments.

- Long run as 5-10 years from implementation of the suggested policy instruments.

${ }^{17}$ E.g. hazardous substances, secondary materials etc. 
In the long run, these positive impacts are expected to offset the negative impact that may occur in the transition phase where the logistics, storage and transportation of recycling or reusing building materials can rise.

Most interviewees stress that impacts are uncertain as current data are considered insufficient and that there is a need to improve and standardise data on waste and consumed building materials.

\subsubsection{Overall COWI estimations}

Few of the interviewees indicate quantified environmental savings or specific financial impacts for private companies, but all of the interviewees have given an indication whether the impact is positive or negative and whether the impact is significant or nonsignificant.

On the basis of the interviewees' impact indications, COWI has collected data from Eurostat, national statistics and an LCA database to make an overall estimation of the impacts of the three summarised groups of policy instruments listed above. The purpose of the overall estimation on the total impact is to give Nordic policy makers a directional view of the magnitude of potential impacts that the interviewees expect from the policy instruments that they have suggested. However, the overall estimations are subject to considerable uncertainties as the interviewees have not specified their expectations and rarely refer to specific analyses or data sources.

COWI's overall estimations reflect the positive expectation that the interviewees have to the environmental impacts and financial impacts for private companies. But it must be kept in mind that the overall estimates are subject to considerable uncertainties. The reason is that it is difficult to quantify these future impacts as the majority of the interviewees have not quantified their expectations and rarely refer to specific analyses or data sources.

In the following, COWI shows the overall results and explains how the assessments have been conducted.

\subsubsection{Environmental impacts}

The environmental impacts are assessed by using two indicators:

- Resource consumption.

- Greenhouse gas emissions in $\mathrm{CO}_{2}$ equivalents.

The interviewees have been asked about the potential saving of primary resources which can be obtained when the proposed policy instrument is implemented. The majority of the feedback from the interviewees indicates that the potential environmental impacts (the use of resources and the consequent emission of greenhouse gasses) will be reduced by $20 \%$ on the long run (the current use of primary resources will be reduced by $20 \%$ - e.g. from $x$ tonnes today to $x$ tonnes $-20 \%$ after the 
policy instrument has been implemented). This estimated potential saving has not been supported by supplementary data as these data is not currently available.

The impact on the environment caused by the suggested policy instruments is calculated based on this expected reduction of $20 \%$ mentioned by the interviewees.

A few of the interviews (from Norway) also provided an estimated reduction of greenhouse gasses.

Simple calculation illustrating the simple calculations made assessing the emissions from one type of resource in one country.

- Country: Norway.

- Type of resource: concrete.

- Amount used today (baseline): 777,000 tonnes/year.

- Savings in primary resources: $20 \%$.

- Future amount to be used when the policy instruments are implemented:

- $777,000-20 \%=621,600$ tonnes.

- Emission factor for concrete: 0.8 tonne $\mathrm{CO}_{2}$-eq./tonne.

- Calculated emission reduction: $(777,000-621,600) * 0.8$ tonne $\mathrm{CO}_{2}$-eq. $/$ tonne $=124,320$ tonne $\mathrm{CO}_{2}$-eq./year.

Based on the estimated change, COWI has made a rough Life Cycle Screening based on existing LCA ${ }^{18}$ data for each type/fraction of resource or building product. ${ }^{19}$ The amounts of resources are then translated into estimated emissions of greenhouse gasses by using LCA-data from the recognised LCA tool GaBi Professional.

The data baseline for the calculations is:

- Amount of waste per year.

- Type of waste split into resource categories.

- LCA data for the emitted amount of $\mathrm{CO}_{2}$ equivalents per type of resource or building product.

The emissions of greenhouse gasses are based on cradle-to-gate LCA data - meaning that the $\mathrm{CO}_{2}$ emission factors include all processes and adhering environmental impacts in all the stages of a product's life from raw material extraction through materials processing, manufacture and transportation of the raw materials, etc.

The data for the quantities of waste per year are used instead of data for the used type and amount of building products as the latter are not available.

The types of resources in the waste differ greatly in the Nordic countries. As information about the types of resources are the key to the calculation of environmental impacts, these data have been collected for this project.

${ }^{18}$ Life Cycle Assessment.

$19 \mathrm{GaBi}$ Professional. 
Also the data for greenhouse gas emissions vary substantially between producers due to different use of energy feedstock for production of the materials, type and availability of raw materials, national or regional energy type etc. As it is recognised that these factors vary, it is decided to use one factor for each type of resource as the purpose of the calculations are to calculate the rough potential gains that interviewees perceive will be achieved.

The data for generated waste in each of the Nordic countries and the potential greenhouse gas emission for each of the resource types are presented in the table below:

Table 4: The generated waste in each of the Nordic countries and the potential greenhouse gas emission for each of the resource types

\begin{tabular}{|c|c|c|c|c|c|}
\hline Tonnes/year & Denmark ${ }^{20}$ & Finland ${ }^{21}$ & Norway ${ }^{22}$ & Sweden ${ }^{23}$ & $\begin{array}{l}\mathrm{CO}_{2-}^{-} \\
\text {eq.[tonnes/tonne } \\
\mathrm{s} \text { of resource }]^{24}\end{array}$ \\
\hline Wood & 108,000 & 142,000 & 262,000 & 250,000 & $\mathrm{~N} / \mathrm{A}^{25}$ \\
\hline Gypsum & 54,000 & N/A & 66,000 & $\mathrm{~N} / \mathrm{A}$ & $0.2^{26}$ \\
\hline Asphalt & 950,000 & $\mathrm{~N} / \mathrm{A}$ & 238,000 & $\mathrm{~N} / \mathrm{A}$ & 0.06 \\
\hline Glass & 5,400 & 30,800 & 9,000 & $N / A$ & 2 \\
\hline Plastic & 1,400 & & 5,100 & $\mathrm{~N} / \mathrm{A}$ & 2.4 \\
\hline Insulation & $15,000-20,000$ & $\mathrm{~N} / \mathrm{A}$ & $\mathrm{N} / \mathrm{A}$ & $\mathrm{N} / \mathrm{A}$ & $0.9^{27}$ \\
\hline Concrete & $1,284,000$ & $\mathrm{~N} / \mathrm{A}$ & 777,000 & 670,000 & 0.8 \\
\hline Bricks & 204,000 & N/A & & & $0.2^{28}$ \\
\hline Stone/soil & $N / A$ & 14,200 & N/A & & $\approx 0^{29}$ \\
\hline Metal $3^{\circ}$ & 52,000 & 1,180 & 87,000 & 330,000 & 2 \\
\hline $\begin{array}{l}\text { Total amount of } \\
\text { waste per year }\end{array}$ & $2,700,000$ & $14,500,000$ & $2,500,000$ & $9,400,000$ & - \\
\hline
\end{tabular}

\footnotetext{
${ }^{20}$ Data for Denmark comes from the report "Kortlægning af genbrugsmarkeder for byggematerialer"from CLEAN (in Danish). The data in this report derives from the waste database hosted by the Danish Environmental Protection Agency. The data are from 2009.

${ }^{21}$ The total amount of waste from Finland derives from the Environmental Ministry report 17/2015. The split into waste types was found in Waste in construction sector in 2013, tonnes (in Finnish: http://www.stat.fi/til/jate/2013/jate_2013_201505-28_tau_002_fi.html

22 Data origins from Statistics sentralbyrå via the link:

https://www.ssb.no/statistikkbanken/selectvarval/Define.asp? subjectcode=\&Productld=\&MainTable=AvfallGenBygg\&nvl= \&PLanguage $=0 \&$ nyTmpVar $=$ true $\& C M S S u b j e c t A r e a=$ natur - og -

miljo\&KortNavnWeb=avfbygganl\&StatVariant=\&checked=true

23 Data is obtained from the publication "Avfall i Sverige 2014" report no. 6727 from June 2016 and published by Naturvårdsverket.

24 The $\mathrm{CO}_{2}$ equivalents are mainly found through various EPDs from EPD Norway's internet page www.epdnorway.no 25 As there is no recognized methodology for the calculation of emission of greenhouse gasses when using, reusing and recycling wood the impact from using wood is excluded. The literature data varies from a great negative numbers (indicating that potential reductions in greenhouse gas emissions can be obtained when using wood) to great positive numbers (indicating that significant emissions of greenhouse gasses occur when using wood).

${ }^{26}$ EPD from Saint-Gobain Gyproc AS for Gyproc ${ }^{\circledR}$ Normal - Standard Plasterboard, 2017

${ }_{27}$ Estimated for glass wool insulation.

${ }^{28}$ The potential emission of greenhouse gasses from the production of bricks is based on the production of red bricks in Denmark.

29 The main impact from sand are typically very low and determined by the transportation distance. As the transportation distances are not known the impact from this resource is excluded.

${ }^{30}$ Assumed to be $100 \%$ steel.
} 
Only the data for reusable and recyclable materials are presented in the table above.

Based on the figures above, rough estimates for the $\mathrm{CO}_{2}$ savings are approximately $3.6 \mathrm{~kg} \mathrm{CO}$-eq. $/ \mathrm{kg}$ of resource that is reduced (applied in the basis scenario). As reuse and recycling also require energy for transportation and processing of the resources it is estimated that only half of the above savings are actually saved (equals approximately $1.8 \mathrm{~kg} \mathrm{CO}$-eq. $/ \mathrm{kg}$ resource).

The process of calculating the greenhouse gas emissions is shown in Figure 1.

Figure 1: The process of calculating the greenhouse gas emissions

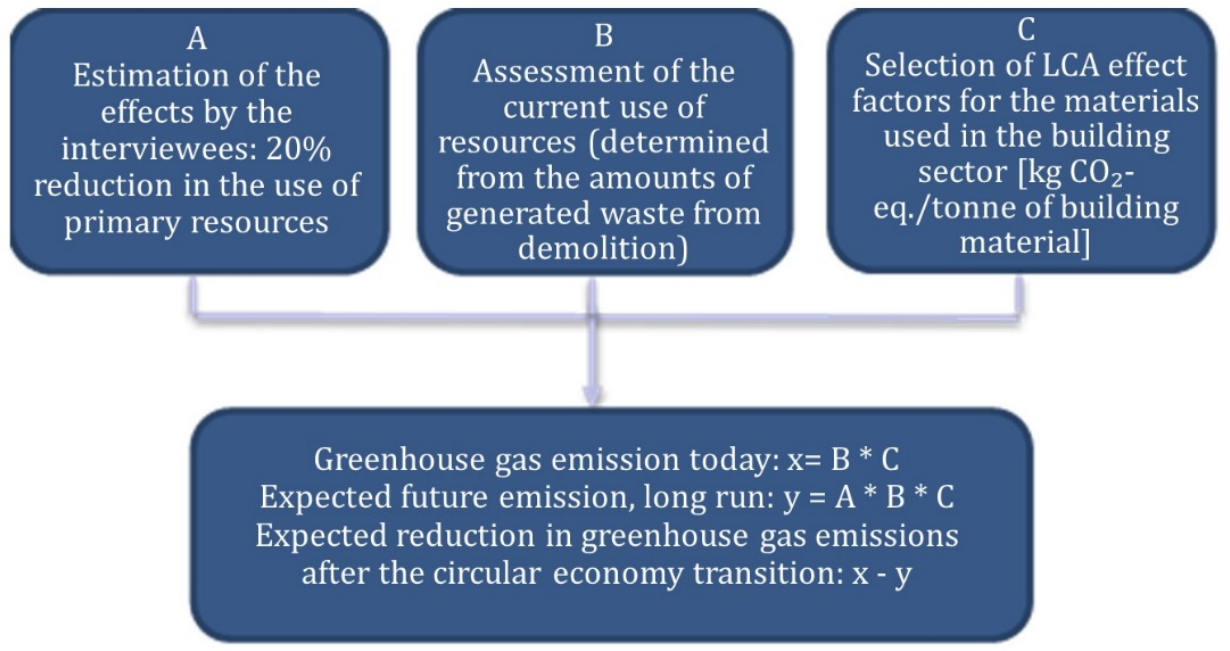

The result of these calculations for each of the four countries is presented below in Table 5 .

Table 5: Potential reductions in greenhouse gasses [tonnes of $\mathrm{CO}_{2}$-eq. per year] - in the basis scenario and for the future scenario

\begin{tabular}{lrr} 
Tonnes of $\mathrm{CO}_{2}$-eq. per year & Basis scenario & Expected emission reductions in the future $\mathbf{2 0} \%$ scenario \\
Denmark & $9,720,000$ & \\
Finland & $52,200,000$ & 972,000 \\
Sweden & $33,840,000$ & $5,220,000^{31}$ \\
Norway & $9,000,000$ & $3,384,000$ \\
Total & $104,760,000$ & 900,000 \\
& & $10,476,000$ \\
\hline
\end{tabular}

A reduction of $20 \%$ in resource consumption results in a potential greenhouse gas emission decrease by approximately 10 million tonnes per year in total for all four Nordic countries including reduced greenhouse gas emissions from the extraction of raw materials, transport and manufacturing phase. As the production of building products and emission of greenhouse gasses may occur in other than the Nordic countries (different to the place where the building product is used) the greenhouse gas

\footnotetext{
${ }^{31}$ The estimated reduction in Finland is expected to be too high as a large part of the waste consist of stone/rock which has a low potential emission of greenhouse gasses.
} 
emission cannot compared to national assessments of greenhouse gas emission. Furthermore, the national assessments often exclude the raw materials extraction - and as this life cycle phase typically is considerable, a comparison with national assessments cannot be performed.

After COWI has aggregated the emission of greenhouse gasses, COWI has multiplied the price per emitted tonne of greenhouse gas by the amount of emitted greenhouse gas. By doing this, the environmental impact (indicated by greenhouse gasses) is translated into costs for the ecosystem services. ${ }^{32}$

For the calculation of the impacts of the potential greenhouse gas emissions on the ecosystem services in monetary terms, a calculation factor for the price of greenhouse gas emissions from Trucost has been applied. Trucost estimates the costs caused by greenhouse gas emissions to the ecosystem services to 86.7 EUR/tonne of $\mathrm{CO}_{2}$ equivalents. ${ }^{33}$

Based on data on the impacts caused by greenhouse gas emissions, the economic consequences of greenhouse gas emissions for the basis scenario (today's situation with the current use and disposal of building products) and $20 \%$ scenario have been calculated by COWI and shown in Table 6 below.

Table 6: : Impacts of the potential greenhouse gas emissions on the ecosystem services in monetary terms in the basis scenario and in the long run ${ }^{34}$

$\begin{array}{lrr}\text { Million EUR/year } & \begin{array}{r}\text { Economic impacts in the basis } \\ \text { scenario }\end{array} & \begin{array}{r}\text { Reduction in the economic impact in } \\ \text { the 20\% scenario }\end{array} \\ \text { Denmark } & 843 & 84.3 \\ \text { Finland } & 4,526 & 452.6 \\ \text { Sweden } & 2,934 & 293.4 \\ \text { Norway } & 780 & 78.0 \\ \text { Total } & 9,083 & 908.3\end{array}$

As can be seen in Table 6, the costs of the potential reductions in greenhouse gas emissions are considerable as the negative impacts in the ecosystem services caused by greenhouse gas emissions are relatively large.

It should be noted that the calculations have been based on the estimated savings in the consumption of primary resources on $20 \%$ which is considered to be a very rough estimate.

It is also assumed that there is an equal distribution of the type of materials (concrete, glass, bricks etc.) in all of the four Nordic countries, and as the reduction of greenhouse gas emissions depends heavily on the type of recycled and reused

\footnotetext{
${ }^{22}$ In the applied methodology the impacts (greenhouse gasses) in the ecosystem services are defined by Trucost as "The net present value of each tonne of carbon dioxide equivalent $\left(\mathrm{CO}_{2} \mathrm{e}\right)$ emitted now, taking into account the full global cost of the damage that it imposes during its time in the atmosphere"according to the publication Trucost's valuation methodology which can be found here: http://www.gabisoftware.com/fileadmin/GaBi_Databases/Thinkstep_Trucost_NCA_factors_methodology_report.pdf 33 http://www.gabi-software.com/fileadmin/GaBi_Databases/Thinkstep_Trucost_NCA_factors_methodology_report.pdf 34 The costs are calculated for the present impacts on the ecosystem services. The method and the costs of emitting greenhouse gasses does not include predictions of future costs. Thus it is estimated that the future gains by reducing the ressource consumption (EUR per emitted $\mathrm{CO}_{2}$-eq.) are the same on the long run as it is today.
} 
resources, these general figures for savings are very rough and thus subject to significant uncertainties.

\subsubsection{Budgetary impacts for public authorities}

The budgetary impacts for public authorities are not estimated as most interviewees view it as cost-neutral; meaning that the administrative costs and expected changes in tax revenues of the suggested policy instruments are viewed as insignificant - in both the long and short run.

The Finnish interviewees, though, find that the policy instruments that they suggest will result in lower administrative costs and thereby have a positive budgetary impact for the public economy. This is most likely due to fact that many of the policy instruments that the Finnish interviewees suggest stand out by having their main focus on simplifying and streamlining chemical and waste regulation through a system based on end-of-waste criteria and standards.

Furthermore, a few interviewees mention an increase in administrative burdens due to increased supervision and oversight when ensuring compliance with the proposed policy instrument. But if all the expected impacts are summarised, the budgetary impact is viewed as cost neutral by the interviewees and COWI has therefore not made overall estimations for the budgetary impacts for public authorities. It is questionable though, if the budgetary impact is neutral as new regulation for a transition toward a circular economy most likely takes additional time to develop, implement and maintain. COWI has reflected upon this in chapter 5 "Reflections".

\subsubsection{Financial impacts for private companies}

The financial impacts for private companies are viewed positively by the interviewees. COWI has chosen gross profit data to reflect this expected impact as the gross profit is the companies' turnover (i.e. market sales of goods or services supplied to third parties) minus their total purchases of goods and services:

- Total purchases of goods and services include the value of all goods and services purchased during the accounting period for resale or consumption in the production process, excluding capital goods (the consumption of which is registered as consumption of fixed capital). 35

- Turnover comprises the totals invoiced by the observation unit during the reference period, and this corresponds to market sales of goods or services supplied to third parties; it includes all duties and taxes on the goods or services invoiced by the unit with the exception of the VAT invoiced by the unit to its customer and other similar deductible taxes directly linked to turnover; it also includes all other charges

35 Definition from Eurostat, quote in Italic: Definitions (INDIC_SB). 
(transport, packaging, etc.) passed on to the customer. Price reductions, rebates and discounts as well as the value of returned packing must be deducted. ${ }^{36}$

The gross profit data for private companies in Denmark, Finland, Norway and Sweden, respectively, are from Eurostat's structural business statistics (SBS). SBS covers activities of the business economy and "describes the structure, conduct and performance of economic activities'. ${ }^{37}$

The Eurostat tables do not match the value chain structure applied in this project. Furthermore, the data for the construction sector include more than the building sector. COWI has therefore selected specific Eurostat tables to construct data that as closely as possible match the value chain structure used in this project.

Data for the value chain structure is constructed by including the following Eurostat tables, where the code refers to the table name in Eurostat..$^{8}$

a) Product design consists of

- C16.22 Manufacture of assembled parquet floors.

- C16.23 Manufacture of other builders' carpentry and joinery.

- C22.23 Manufacture of builders' ware of plastic.

- C23.31 Manufacture of ceramic tiles and flags.

- C23.32 Manufacture of bricks, tiles and construction products, in baked clay.

- C23.61 Manufacture of concrete products for construction purposes.

- C23.62 Manufacture of plaster products for construction purposes.

- C23.65 Manufacture of fibre cement.

b) Design of building consists of

- M71: Architectural and engineering activities; technical testing and analysis.

c) Production process and e) Refurbishment has been merged as refurbishment is viewed as a re-design of buildings, and consist of

- F41.20 Construction of residential and non-residential buildings.

- F43.22 Plumbing, heat and air conditioning installation.

- F43.3 Building completion and finishing.

- F43.9 Other specialised construction activities.

${ }^{36}$ Definition from Eurostat, quote in Italic: Definitions (INDIC_SB).

${ }_{37}$ Quote from http://ec.europa.eu/eurostat/web/structural-business-statistics

${ }^{38} \mathrm{http}: / /$ ec. Europa.eu/Eurostat/documents/3859598/5902521/KS-RA-07-015-EN.PDF 
d) Consumption/use is not included as none of 16 interviewees highlight this part of the value chain when addressing the impact of the policy instruments that they suggest

\section{f) From waste to resources consist of}

- F43.11 Demolition.

To create a baseline, COWI has found the total average of the construction sector with the latest available Eurostat data, which are 2010-2014 (current prices). The total baseline in 2018 prices is 57,775 billion EUR for private companies in the construction sector in Denmark, Finland, Norway and Sweden respectively.

The interviewees expect significant and positive financials impacts for private companies, but they did not specify the expected percentage change.

The Ellen MacArthur Foundation report, "Potential for Denmark as a Circular Economy" (2015) includes an impact assessment for the expected impact of "expanding the reuse and high-quality recycling of building components and materials by applying design for disassembly techniques, material passports, innovative business models, and setting up a reverse logistics ecosystem". The focus is broadly equivalent to the focus of the policy instruments that the interviewees have suggested. In that impact assessment, COWI has calculated that the team from Ellen MacArthur Foundation has set the annual impact rate to $1.7 \% 39$ as the basis for estimating the potential annual savings in the construction sector.

For the overall estimation, COWI has therefore set the expected total growth in gross profit to $1.7 \%$ per year after a full implementation of the policy instruments suggested by the interviewees. COWI also applies this annual growth rate to the construction sector in Finland, Norway and Sweden.

COWl expects the implementation period to be 5 years. This is due to the expected process of improving documentation of the technical performance (quality, durability, strength, content of hazardous substances etc.) of building materials, improving traceability of the content of building materials as well as minimum standards for recyclability and reuse of building materials.

After a full implementation of the suggested policy instruments, COWI assumes the gross profit to increase by the full $1.7 \%$ p.a. as the looping of high-quality building materials will be reflected in the design of building materials and building. It will make the recycling and reuse processes more efficient and cost effective, and it will cut the companies' costs for logistics services and recycled materials.

Based on this growth rate, a 5 year implementation period and a discount rate of 4 $\%,,^{40} \mathrm{COWI}$ has made overall estimation for the long run net present (2018) impact for

\footnotetext{
39 See figure $\mathrm{B}_{5}$, page 104 in the appendix to "Potential for Denmark as a Circular Economy. A case study from: delivering the Circular Economy - A toolkit for policy makers':

$4^{\circ}$ Which is the recommended discount rate in year 0-35 in "Vejledning i samfundsøkonomiske konsekvensvurderinger, 2017" (august 2017), table 4.1, page 46: https://www.fm.dk/ /media/publikationer/imported/2017/vejledning-

samfundsoeko-konsekvensvurderinger/vejledning-i-samfundsoekonomiske-konsekvensvurderinger_web.ashx
} 
the first year (2023) of a full implementation of the policy instruments that the interviewees suggest.

The overall estimation shows a first year total growth in gross profit of 803 million EUR (in 2023), compared to the total baseline. It equals 140, 120, 244 and 298 million EUR in Denmark, Finland, Norway and Sweden, respectively. The table below illustrate the $1.7 \%$ annually growth rate as well as a $1 \%$ and $3 \%$ annually growth rate to show a more conservative and ambitious overall impact estimation.

All overall estimations are subject to considerable uncertainties as the interviewees have not specified their expectations and rarely refer to specific analyses or data sources.

Table 7: 1\%, 1.7\% and $3 \%$ annually growth in gross profit in million EUR (2018 prices) from first year of implementation compared to the baseline (average of $2010-2014$ in 2018 prices)

\begin{tabular}{|c|c|c|c|c|}
\hline & Baseline & $1 \%$ & $1.7 \%$ & $3 \%$ \\
\hline Denmark & 10,061 & 83 & 140 & 248 \\
\hline Finland & 8,628 & 71 & 120 & 213 \\
\hline Sweden & 21,486 & 177 & 298 & 530 \\
\hline Norway & 17,600 & 145 & 244 & 434 \\
\hline Total & 57,775 & 475 & 803 & 1,425 \\
\hline
\end{tabular}





\section{Reflections}

Circular economy is becoming a widely accepted way to create resource efficient growth. The approach is supported by the Nordic governments and circular economy is used as a driver for business development in various companies in the Nordic region. Still, the circular economy has yet to be established as a widespread business driver. This also applies to the construction sector.

Today, few buildings are built based on or inspired by a circular economy approach. This explains the significant amount of waste from the construction, refurbishment and demolition of buildings, and it indicates that many are reluctant to pursue a more circular based business approach as this is currently not financially viable in most building projects.

The 32 policy instruments that the 16 interviewees suggested can speed up the transition toward a circular economy and ensure significant gains: especially concerning the environmental impacts. But the transition can be complicated and the transition process needs to address a number of barriers that may hinder the positive impacts that the interviewees have estimated and for which COWI has made rough calculations.

According to COWI the main barriers are currently:

- Lack of (early stage) value chain corporation and partnership in the construction sector. Product designers, building designers, constructors, demolition companies and waste managers need to work more closely together in order to agree how (and if) everyone can commercially benefit from more circular based approaches. As an example, the degree of reusability depends on the design of both products and buildings, including the logistics and warehousing of the resources and building products before they can be recycled or reused. In the short run, it will take investments and a transition phase with trial and error - like any other business development. The business development must include new and early dialogue across the whole value chain in order to find feasible circular solutions that are profitable for everyone. But like in any other businesses, demand drives development.

- Lack of economy of scale. If only few companies have implemented a circular approach, the marginal costs are most often high and the marginal revenues are equivalently low. Logistics and warehousing of often heavy materials is a prime example of what drives costs. Furthermore, most building materials are produced in low-wage countries and their value chains are efficient and relatively low cost. Larger scale and volume on both the supply and demand side of recycled and reused materials is needed to make a circular business approach profitable and financially sustainable. 
- Lack of quality assurance marking schemes with e.g. CE marking of reused building materials requires construction and building owners to take risks. ${ }^{41}$ For new products, the material producer is responsible for the quality of the product they sell and they can be held accountable for any defect product. Likewise, this responsibility is also needed for reused products. A quality assurance process or mechanism must be established to reduce the risk of sourcing reused building materials.

- The content of hazardous substances in existing building products. As existing buildings containing old building products will be demolished during the coming years, the potential for short term environmental gains to be achieved demands identification and removal of these substances prior to any reuse and recycling.

- The current focus on the weight of the building materials which are high in the building sector - but which does not necessarily reflect the potential for significant improvements of the resource efficiency. It could be considered to change the fulcrum E.g. to the volume of building materials, resource scarcity related to the building products or other measures.

According to COWI, the main barriers are to a high degree interrelated. Targeted efforts are therefore required - by companies and/or public authorities - to overcome inherent traditions in the construction sector. Multi-faceted and collaborative efforts are required to reach the full impact potentials of a transition to a circular economy.

Public authorities and large private companies have a key role in creating a large scale demand of building designs based on a circular business approach and in facilitating the needed dialogues and processes. Growing and fluctuating resource prices and growing user demands for healthy materials, flexibility and in general more sustainable solutions improve the business case for doing so.

Facilitating such dialogues and processes may have budgetary impact for public authorities. The question is if new regulation for a transition toward a circular economy will too. A few interviewees mention an increase in administrative burdens due to increased supervision when ensuring compliance with the proposed policy instrument. But when all the expected impacts are summarised, the budgetary impact is viewed as cost neutral by the interviewees.

Supervision might be included in existing budgets, but the development, implementation and maintenance of a circular economy scheme based on the suggested policy instruments will most likely have a budgetary impact.

A circular economy based approach will be new to the construction sector as a whole. New business and sourcing models needs to be developed along with new design approaches, new workflows and new logistic solutions to support the circulation of building materials. This needs to be regulated by public authorities to

${ }^{41}$ The CE marking aims to ensure the reliability of information on the performance of construction products which is achieved through harmonised European product standards and European Technical Assessments using a common technical language and uniform assessment methods. It places obligations on manufacturers, distributors and importers of construction products when CE marked products are placed on the market. 
live up to the intension behind the suggested policy instruments, and the supervision and compliance hereto will most likely have a budgetary impact for public authorities - also in the longer run.

Furthermore, from the perspective of policy makers, new rules and regulations can most likely not stand alone as there will be a need for strong economic incentives for companies to change their existing and often linear business approaches. New taxation structures, fees and financial support through public programmes can create such incentives. Creating such incentives will also have a budgetary impact for public authorities.

The policy instruments cannot be prioritised (listed according to their effect on the circular economy) due to:

- The assessment of impacts is based on a very narrow basis of data (a brief literature review and statements from 16 interviewees).

- There are significant differences between countries.

- The definitions of waste, recycled resources etc. have not been decided upon in several Nordic countries. Thus, the data baseline is not the same for all countries and differences are also observed at a national level - making it difficult to assess the real potential of the circular economy transition in the construction sector.

- Only specific impact categories are included. If more impact categories are included, the conclusions could be weaker or stronger depending on the data basis. 



\section{Country summaries}

A summary is made for each of the four Nordic countries: Denmark, Finland, Norway and Sweden. The summaries highlight the status and latest development in the transition toward a circular economy in the construction sector, as they highlight the main points from the interviews with the interviewees.

\subsection{Denmark}

The current status of a transition toward a circular economy in the construction sector in Denmark is characterised by:

- Ambition to improve the quality of recycling of materials from the construction sector. Preferably increased direct reuse.

- Removal of hazardous substances in building materials.

These goals are expressed in:

- The two Danish resource strategies..$^{42}$

- The Danish prevention strategy. ${ }^{43}$

- Recommendations from the Advisory Board for Circular Economy.

The waste prevention strategy is a continuation of the resource strategies. With these strategies, the Government's ambition is to contribute to the decoupling of economic growth and environmental impacts from waste generation.

The waste prevention strategy describes a number of initiatives for the construction sector which aims at waste prevention and more efficient use of resources.

The Advisory Board for Circular Economy has delivered 27 recommendations to the Danish Government, 4 of which are directly related to the construction sector with the goal of strengthening efficiency, providing access to new markets and solidifying Danish businesses within the circular economy agenda. Several other recommendations are also important to the construction sector indirectly. Examples are:

- Ensure that circular economy is a driver for growth for Danish companies including establishment of partnerships, forums and networks.

${ }^{2} \mathrm{http}: / / \mathrm{mst} . d k /$ virksomhed-myndighed/affald/affaldshaandtering-strategi-aktiviteter/danmark-uden-affald-strategi-plan/ 43 http://mst.dk/media/131357/danmark_uden_affald_ii_web_29042015.pdf p. 34 
- Establish one access point for the companies to the public authorities - e.g. by using Green Deals to remove barriers for increased circular economy.

- Establish circular municipalities by removing strict obligations that hinder increased circular economy.

- Incorporate circularity in the macroeconomic models and statistics. The improved statistical basis should facilitate improved data for calculation of the environmental benefits of increased circular economy.

- Develop standards supporting the circular economy transition - e.g. by documenting the quality of reused building materials and building products with secondary materials.

- Promoting research, development, tests, demonstration project and market maturity of circular solutions and technologies.

- Improve the circular product policy in e.g. the Ecodesign Directive e.g. by improving principles and products which comply with the Design for Disassembly principles.

- Development of a circular building regulation.

- Development of standardised building passports and product passports.

- Create clear framework conditions in the waste sector and improved supply of secondary materials, including abolishment of municipalities' right to allocate waste.

- Improve the competition in the waste market and secondary resources through uniform classification of waste and increased risk-based site inspection.

- Increase selective demolition for all buildings to be demolished.

The policy instruments that the interviewees from Denmark suggest mainly focus on rules and regulations, with a secondary focus on taxes, information and agreements. The main aspects mentioned are:

- A new public regulatory policy initiative that strengthens the responsibilities of the building owner to choose new building materials with a share of secondary materials.

- Requirements for the development of a building passport when constructing new buildings to enable increased reuse and recycling of materials on the renovation or demolition of buildings.

- Changing the waste legislation by setting up requirements for a demolition plan to increase recycling and reuse of secondary resources.

- Stimulating the use of the above-mentioned policy instruments by documenting the content, strength etc. of building materials and products to support improved conditions for recycling and reuse. 
One interviewee mentioned a specific policy instrument which is not included in the main aspects mentioned above. Nevertheless it is included to reflect the variance in the answers and the very large differences depending on the interviewees' perspective and role in the market:

- Dispensation from the capital cost ceiling for the Danish municipalities for construction works ("anlægsloftet"). Dispensations should be given for municipal construction of buildings that are based on the principles of Circular Economy demanding the use of recycled and/or reused materials in new buildings. Dispensations are expected to create a significant demand for building designs and construction products based on the principles of Circular Economy and thus support the creation of a market for secondary raw materials.

Summing up, the suggested policy instruments are mainly focusing on:

- New requirements to be incorporated into the building regulations that affect the incentives and requirements to produce and acquire reused building products and building materials including secondary resources.

- Strengthened requirements for the documentation, supervision and sorting of materials in the demolition phase.

The suggested policy instruments mainly relate to the building regulation (Bygningsreglementet) and the waste regulation (Affaldsbekendtgørelsen).

If the main suggested policy instruments are implemented, they will mainly create an opportunity for new business models. This is expected to:

- Have a strong positive impact on the environment - due to reduced use of primary resources and increased recycling for high-value purposes of secondary raw materials and products.

- Have a low negative impact on the public economy due to increased supervision of demolitions and lower VAT on reused building products and building materials containing secondary resources.

- Have a positive impact on the economy for private companies (building materials producers, demolition companies and waste handling companies) that develop or adjust business models to the overall trend of more resource efficient and circular practices.

The following policy instruments were mentioned by the interviewees in Denmark. 
Table 8: Denmark

Organisation

The Danish Environmental Protection Agency (a)

Danish Waste Association (b)

The Centre for Management and Recycling of Construction Waste (c)

Confederation of Danish Industry (d)

\section{Policy instrument}

1a: Increased demands/requirements for the development of a demolition plan.

2a: Incorporation of new green criteria with focus on increased quality of recycling and increased reuse of resources into the national building regulation in Denmark.

1b: The limited and restricted capital cost ceiling for the Danish municipalities for construction works. Dispensation from exceeding the capital cost ceiling. Guide to supplement this dispensation from the capital cost ceiling for the construction works in Danish municipalities.

Requirements concerning e.g. the use of $20 \%$ reused/recycled materials in new buildings etc.

2b: Equal tax on building materials - no dependence on the content of reused and/or recycled materials.

1c: Motivation of and/or setting requirements in the national building regulation to the private and public building owners in order to promote construction that supports the principles of the Circular Economy. $2 \mathrm{c}$ : Regulation concerning the responsibility of the building owner: the building owner is responsible for carrying out screening (and mapping) of the building materials prior to certain types of construction/renovation works or demolition to determine whether PCB-containing material may have been used in the construction or any previous renovation of the building. Furthermore, the building owner is responsible for submitting a written notification to the municipal council covering (among other information) the expected waste quantities and types as well as expected use or treatment of the waste and the expected waste recipient.

1d: Removal of the obligation to use the municipal waste handling solution as the most important starting point to accelerate an effective market with reused building products and recycled resources.

$2 \mathrm{~d}$ : The policy instrument is the lack of requirements for the technical performance and quality of the reused products or the products including recycled resources in the Construction Products Regulation.

A declaration of a building material/products' technical performance (quality, durability, strength, content of hazardous substances etc.) is needed to ensure the quality level of buildings.

\subsection{Finland}

The current status of a transition toward a circular economy, including the construction sector, in Finland, is characterised by:

- The goal of at least $70 \%$ of all construction waste to be used as secondary material by 2016, and $5 \%$ (3-4 million tonnes) of gravel and crushed stone used in earthworks to be replaced by waste generated by industry and mineral extraction by 2016 . 
- The focus of the current national waste management plan ${ }^{44}$ has been to increase the resource efficiency for new construction work by:

- Using an environmental classification system for buildings to promote resource efficiency.

- Increasing the use of recycled materials in earthworks carried out in projects covered by the central and local government public procurement.

- Improving the efficiency of the environmental permitting system.

- In 2012, approximately 16 million tonnes of construction and demolition waste were generated; approximately 14 million tonnes of soil waste and 1.5-2.0 million tonnes from buildings. $45 \mathrm{It}$ is estimated that current utilisation of construction and demolition waste is approximately $60 \%,{ }^{4}$ h however, due to the state of construction and demolition statistics, this figure is surrounded by a high degree of uncertainty.

- The draft National Waste Management Plan for 2023 establishes construction waste as a priority area. Four goals have been set: to decrease the amount of house construction waste; to increase material recovery of construction waste to $70 \%$; to increase the utilization of construction, demolition and earthwork waste while considering risk management; and to increase the accuracy of construction and demolition waste statistics.

The policy instruments that the interviewees from Finland suggest mainly focus on regulatory instruments and their main aspects are:

- The implementation of planned regulatory instruments to reduce the regulatory burden of environmental permitting related to earthworks (moving from a caseby-case approach to a standard based approach) with the intent to facilitate an increase in the reuse and recycling of construction and demolition waste arising from earthworks.

- The introduction of resource efficiency requirements for construction and renovation activities with the intent to increase resource efficiency in the building sector.

- The extension of eco-design and standardisation requirements, with special reference to prefabricated modular elements in the construction sector, with the intent to facilitate the reuse of wooden construction elements.

- The digitisation of waste shipping documents and the requirement to perform pre-demolition audits with the intent to improve the quality of construction and demolition waste data.

\footnotetext{
44 Ministry of the Environment, 2009. Towards a recycling society - The National Waste Plan for 2016. The Finnish Environment 14/2009

45 Biolntelligence Services et al., 2015. Construction and Demolition Waste Management in FINLAND V $3-$ December 2015 ${ }^{46}$ Salmenperä et al. 2016. Kohdennetut keinot kierrätyksen kasvuun. Valtioneuvoston selvitys- ja tutkimustoiminnan julkaisusarja 53/2016
} 
- The need to harmonise waste and product policy, especially concerning end-ofwaste provisions with the intent to stimulate investment, innovation and the development of secondary raw materials and markets.

Summing up, the suggested policy instruments mainly focus on:

- Earthworks, concrete building foundation elements and facades, and wooden building elements.

- Waste fractions, including soil and materials from earth works, concrete tiles, bricks and masonry and wood

- The end-of-life of building materials, although some instruments focus on product design.

The suggested policy instruments mainly relate to regulatory instruments in terms of environmental permitting procedures, end-of-waste provisions and the improvement of waste statistics.

If the main suggested policy instruments are implemented, they will mainly create an opportunity to increase the amount of reused and recycled construction and demolition waste due to less regulatory burdens and uncertainty, as well as improved statistics.

This is expected to have:

- A medium positive impact on the environment, due to simplified environmental permitting procedures and the clarifications of end-of-waste for waste materials.

- A small to medium positive economic impact on the public sector, due to the reduced regulatory burden on public authorities and reduced landfill tax stemming from public sector construction works.

- A small to medium positive economic impact on private companies due to reduced regulatory burden on the industry, increased market certainty for secondary raw materials and thus stronger investment in material recovery solutions.

The following policy instruments were mentioned by the interviewees in Finland. 
Table 9: Finland

\section{Organisation}

Finnish Environmental Industries (YTP) (e)

Helsinki Region Environmental Services Authority HSY ( $f$ )

Confederation of Finnish Construction Industries RT (g)

Finnish Environment Institute (h)
Policy instrument

1e: Integrating chemical and waste policies to support the exploitation and reproduction of recycled materials 2e: Streamlining regulations and simplifying quality assurance processes

1f: Regulations for resource efficiency in renovation and construction through a classification system 2f: Reduce the regulatory burden of waste permitting common environmental criterion for construction waste and allowing certain waste fractions to be recycled without having to apply for an environmental permit on a case-by-case basis

1g: Reduce the regulatory burden of waste permitting: common environmental criterion for construction waste and allow certain waste fractions to be recycled without having to apply for an environmental permit on a case-bycase basis

2g: Integrating chemical and waste legislation to support each other and have a common goal

1h: Better provision of information concerning the amount and content of waste in the construction sector 2h: Enforcement of the Ecodesign Directive for prefabricated units: standardising

\subsection{Norway}

The current status of a transition toward a circular economy in the construction sector in Norway is reflected in the Norwegian waste strategy "From Waste to resources", which contains the following goals:

- The total quantity of waste shall be considerably lower than the growth in the economy.

- The quantity of waste for recycling (75\% in 2010) shall gradually rise to $80 \%$ in line with what is economically and environmentally sound.

- All hazardous waste should be taken care of properly.

- The generation of hazardous waste shall be reduced before 2020 (compared to 2005 level).

- There is a newly prepared Annex (Waste Prevention Program) to the Strategy which is currently being considered (deadline 30.6.2017).

So far, there are no direct goals for increased circular economy in the construction sector in Norway. Norway has, however, adopted requirements in the Building Regulation (TEK) for the preparation of waste plans when building a new building, when buildings are renovated and when buildings are demolished. There is also a requirement 
for the preparation of an environmental assessment plan prior to demolition to identify and remove hazardous waste separately. Further, it is required that at least $60 \%$ of the construction waste is sorted at the site of construction. Sorted combustible waste does not count as a separate fraction and mixed residual waste cannot exceed $40 \%$ of the total amount. In exceptional cases acceptance may be given to sort the waste at a sorting plant instead of at the building site.

The Federation of Norwegian Construction Industries (BNL) took the initiative to create the first national Action plan (NHP1) on construction waste in 2001. Then approximately $80 \%$ of the construction waste ended at a landfill while now more than $80 \%$ are recycled. An overall goal in $\mathrm{NHP}_{3}$ is that all construction waste should be sought minimized and secured as high as possible recycling and proper handling. It is important to stress that even though a high percentage of the waste is recycled (resources and energy), this also includes waste that substitutes other virgin products for construction purposes which leads this waste out of the circle; meaning that the waste will not be included in other construction products and be part of a new life cycle. Examples in this regard is the use of recycled concrete as noise embankment, and recycled wood used for energy recovery in incinerators.

The policy instruments suggested by the Norwegian interviewees mainly focus on regulation, rules, documentation and information. The main aspects are the following:

- Stricter documentation requirements for all building products used for new construction. This with the intent to make the building materials more traceable and consequently increase the amount of reused building materials in the construction sector.

- Expanding the requirement for a waste plan in the building legislation to apply for all buildings (Technical building regulation (TEK) $\$ 9-6$ ).

- Increasing the recycling rate demand from building and construction waste, and the requirement of a certain content of secondary resources in new products. This implies adopting stricter recycling goals in the waste legislation, which again has to be implemented in the building legislation.

- Enhancing competencies within circular economy by focusing more on industrial symbiosis between industries, not just within the construction sector.

Summing up, the suggested policy instruments mainly focus on the production and demolition phases. It is mainly the building owner and the waste sector that is affected by these policy instruments. All building components are included in these policy instruments.

If the main suggested policy instruments are implemented, they will mainly create an opportunities for producers of building products due to stricter documentation requirements, this apply especially to policy instruments i and k. For policy instrument $\mathrm{j}$ this will create opportunities for the waste sector, also due to stricter requirements to document an increased amount of sorted waste. Policy instrument I will create opportunities for the whole construction sector due to increased knowledge within 
circular economy, products, and co-operations between different sectors also outside of the construction sector itself.

In the short and long run, the policy instruments are expected to have:

- A positive impact on the environment - due to the fact that the use of primary resources will most likely be reduced and with fewer pollutants in the buildings.

- A neutral impact on the public economy. Follow-up to ensure compliance with the building regulations will require some additional work. Since the public authorities normally cover their costs through fees and taxes, it will imply that the building application fee will increase slightly. The effect on the economy for public authorities is thereby estimated to be neutral.

- Another positive effect is that emissions will be reduced as the withdrawal of virgin raw materials usually generates much higher emissions of greenhouse gasses. The possible mixture of recycled waste as a secondary resource varies between the different products/components and the effect will thereby also vary.

- A small positive impact on the economy for the private companies. There will not be an additional cost - on the contrary this will benefit the private companies due to increased knowledge; improved technologies, business models, exploration of building materials and products etc.

The following policy instruments were mentioned by the interviewees in Norway.

\section{Table 10: Norway}

\section{Organisation}

The Federation of Norwegian Industries (i)

The Federation of Norwegian Construction Industries ( $\mathrm{j}$ )

The trade organisation Bygg uten Grenser (k)

Norwegian Association of Heavy Equipment Contractors) (l)

\section{Policy instrument}

1i: Increase the recycling rate requirement for building and construction waste. This implies adopting stricter recycle goals in the waste legislation, which again has to be implemented in the building legislation.

2i: Requirements for a waste plan in the building legislation to apply for all buildings (Technical building regulation (TEK) \$9-6).

1j: Require a certain content of recycled resources in new products in the national building regulation. 2j: Introduce stricter documentation requirements for all materials used for new construction in the national building regulation (a building passport)

$1 \mathrm{k}$ : Traceability for building materials/products in order to make it easier to reuse and recycle by altering the building legislation. Environmental labelling of all building materials and products to be made mandatory. $2 k$ : Increase the knowledge regarding circular economy by focusing more on industrial symbiosis.

1): Requirements for the preparation of a waste plan, environmental management description and sorting requirements in the building regulations for all sizes of new construction, demolition and refurbishment projects. 21: Requirements for documentation of all materials used for new construction in the national building regulation (a building passport). 


\subsection{Sweden}

The current status of a transition toward a circular economy in the construction sector in Sweden is characterised by:

- The construction industry should adopt measures for materials reuse, recycling and other measures on non-hazardous construction and demolition waste to achieve materials recycling on a level of $70 \%$ by weight. 47,48 by 2020 .

- Hence, it is a key focus to minimize the use of hazardous materials as a measure to increase the potential for recycling and reuse.

- A key factor in analysing the present state in Sweden is the low quality of statistics on materials flows and other relevant facts. This is best characterised by the Swedish EPA, which identifies that Sweden probably has reached the 2020 goal already.

- Apart from the public policy framework, there are also voluntary private sector agreements that affect resource efficiency and that are broadly applied in the sector. ${ }^{49}$ Examples of such initiatives are BASTA, ${ }^{50}$ Byggvarubedömningen ${ }^{51}$ and Sunda Hus, ${ }^{52}$ but also certification schemes such as Miljöbyggnad, ${ }^{53}$ BREEAM and LEED.

The policy instruments that the interviewees from Sweden suggest mainly focus on rules and agreements, with a significant secondary focus on information and statistical improvements, and their main aspects are:

- A new public regulatory policy initiative that strengthens the responsibilities of contractors to sort recyclable and reusable resources in construction and demolition.

- A new public regulatory policy initiative establishing a mandatory quota for use of recycled/reused resources in construction to stimulate business developments within resource efficiency.

- Changing the waste legislation to acknowledge the environmental relevance of recycling and reuse rather than measuring weights and volumes, so as to stimulate more effective business models within resource efficiency.

\footnotetext{
47 http://www.naturvardsverket.se/Miljoarbete-i-samhallet/Sveriges-miljomal/Etappmal/

${ }^{8} \mathrm{It}$ has been estimated by the Swedish EPA that the goals is probably reached already, but that the statistical data quality is of very low quality and that the conclusion thus lacks some robustness.

https://www.miljomal.se/Global/24_las_mer/rapporter/malansvariga_myndigheter/2016/etappmalen-2016.pdf

49 Private initiatives are similarly included in the policy overview in the sector performed by the Swedish EPA, https://www.regeringen.se/contentassets/c286a4ac8d8042ag826649obc13ddf7d/naturvardsverkets-redovisning-avregeringsuppdrag-icke-farligt-byggnads--och-rivningsavfall.pdf.

$5^{\circ}$ http://www.bastaonline.se/

${ }^{51}$ https://www.byggvarubedomningen.se/

${ }^{2}$ https://www.sundahus.se/

53 https://www.sgbc.se/var-verksamhet/miljoebyggnad
} 
- Changes to public administrative and economic policy instruments that regulate and affect the market for energy (combustion) and materials recycling of wastes with the intention to increase materials recycling through changes of the economic incentives of energy versus materials recycling, where the former is seen as favourable by some market actors.

- Changes to regulatory policies on waste management so as to improve possibilities for municipalities to work with reuse at recycling centres in order to improve the efficiency of the centres and reuse public and small-business materials otherwise treated as waste.

- Stimulating the use of the above-mentioned policy instruments (i.e. agreements) to document and minimise the use of hazardous materials in buildings in support of improved conditions for recycling and reuse.

Summing up, the suggested policy instruments mainly focus on:

- Broad policies that affect the incentives and requirements to recycle and reuse (it is considered difficult to point out specific material resources and building components).

- Minimising the use of chemicals and hazardous materials and improving incentives for new business models.

The suggested policy instruments mainly relate to The Environmental Code (Miljöbalken), ${ }^{54}$ the Waste Ordinance (Avfallsförordningen) ${ }^{55}$ the Ordinance on the Landfill of Waste ${ }^{56}$ and the Waste Tax (Deponiskatt). ${ }^{57}$

This is expected to:

- Have a strong positive impact on the environment - due to reduced use of chemicals and hazardous materials, while quantified estimates are deemed difficult due to the low quality of statistics.

- Have a medium positive impact on the public economy - where new businesses will contribute to the economy and potentially lower the need for virgin materials. Negative impacts of the economy due to lower VAT and policy instrument revenues. Quantified estimates are difficult to make.

\footnotetext{
54 https://www.riksdagen.se/sv/dokument-lagar/dokument/svensk-forfattningssamling/miljobalk-1998808_sfs-1998-808 55 https://www.riksdagen.se/sv/dokument-lagar/dokument/svensk-forfattningssamling/avfallsforordning-2011927_sfs2011-927 ${ }^{6}$ https://www.riksdagen.se/sv/dokument-lagar/dokument/svensk-forfattningssamling/forordning-2001512-omdeponering-av-avfall_sfs-2001-512

57 http://www.notisum.se/rnp/sls/lag/19990673.htm
} 
- Have a strong positive impact on the economy for the private companies that develop or adjust business models to the overall trend of more resource efficient and circular practices. Statistics do not support quantified estimates.

The following policy instruments were mentioned by the interviewees in Sweden.

Table 11: Sweden

Organisation Policy instrument

Svensk Byggindustri $(\mathrm{m})$

The Swedish Recycling Industries Association (n)

Avfall Sverige (o)

IVL Svenska Miljöinstitutet (p)
$1 \mathrm{~m}$ : Resource and waste guidelines for the construction sector. This initiative is informative and the goal is to make resources out of waste. $2 \mathrm{~m}$ : Information and guideline systems and agreements.

This concerns a set of initiatives by providing guidance on material contents in construction resources and to some extent also to document this information through different databases. The aim is to reduce the chemical and hazardous contents of building materials and thus support the reuse or materials recycling in future (and improve healthy living conditions).

1n: Development of public regulatory policies that controls the responsibilities and possibilities of municipalities to act as a stakeholder within the waste, recycling and reuse system.

$2 n$ : Changes to public administrative policy instruments, mainly targeting the Environmental Code. The aim is to define the role of other stakeholders (activities/organisations/companies) other than municipalities. These changes thus concern the development of a public regulatory policy instrument that controls the responsibilities and possibilities of municipalities to act as a stakeholder within the waste, recycling and reuse system.

10: The development of a milestone/goal of materials recycling in the construction industry reaching $70 \%$ of non-hazardous materials before 2020 . This is a public policy target, which is not established as a legal requirement on single policy subjects and thus to be considered an informative policy. It has a direct impact on the whole of the construction sector through setting an overarching target for the industry. The intentions of the goal is to provide guidance both to public and private stakeholders and groups. 20: Improved possibilities for municipalities to work with reuse at recycling centres which concerns a suggested change to an administrative (regulatory) public policy instrument. The change is suggested in the recent Government Report on circular economy. The aim is to rectify a situation where there has been a legal impediment (or rather a legal void) for municipalities to significantly engage in reuse at their recycling centres.

1p: Changing the waste legislation to acknowledge environmental relevance which concerns development of both public informative policies and public administrative policy instruments that inform and control the function of the waste system. The intention is to replace the current goal, which emphasizes weight, and replace this with a goal that acknowledges the environmental benefits.

2p: Changes to public administrative and economic policy instruments that regulate and affects the market for energy and materials recycling of wastes. The aim is to increase materials recycling through changing the economic incentives of energy versus materials recycling, where the former is seen as favourable by some market actors. The intention is to stimulate a market development and innovation towards materials recycling of fossil waste resources. It affects the majority of the construction sector, excluding only the stakeholders that exclusively deal with non-fossil construction resources. 


\section{Conclusions and recommendations}

Sixteen interviewees have pointed at 32 new policy instruments that they find are needed the most to accelerate a transition toward a circular economy in the construction sector in Denmark, Finland, Norway and Sweden.

Of the 32 new policy instruments, most are focusing on new rules and regulation. Few are focusing on the need for new economic incentives, new agreements or providing new information.

The suggested new rules and regulation mainly focus on:

- Product design and especially the design and demolition of buildings.

- Resources such as concrete, tiles, bricks and masonry, wood and insulation material.

- Building components such as the facade, the foundation, windows and insulation.

- Anchoring the suggested rules and regulations in the building regulation in Denmark, Finland, Norway and Sweden and secondly in:

- Environmental Product Declarations (EPD)..$^{8}$

- Construction Products Regulation (CPR). 59

- Building Information Modelling System (BIM).

- Material passports and/or building passports

The new rules and regulation that the interviewees mainly suggest can be summarised into three main policy instruments:

1. Requirements for documentation of the content ${ }^{60}$ and quality of the building materials with a main focus on the technical performance, the recycling rate, the traceability of the building materials and on sharing this information in a database.

2. Requirements for the documentation of the use of reused building products and building products containing recycled resources and in buildings with a main focus on setting minimum requirements, green resource efficient criteria and quota for the share of reused building products and building products containing recycled

\footnotetext{
${ }^{8}$ See http://www.environdec.com/en/What-is-an-EPD/

59 See https://ec.europa.eu/growth/sectors/construction/product-regulation_da

${ }^{60}$ E.g. hazardous substances, secondary materials etc.
} 
resources in buildings. Information about the selected building products in buildings are suggested to be documented in "building passport".

3. Requirements for waste and demolition plans with a main focus on screening, mapping and sorting valuable building products for reuse and recyclable resources and on setting minimum recycling rates and end-of-waste criteria and on providing guidelines and training for demolition companies.

These policy instruments will require improved documentation of the technical performance (quality, durability, strength etc.), content of hazardous substances etc. of building products, improved traceability of the content of building materials as well as minimum standards for recyclability and reuse of building materials.

Such documentation, traceability and minimum requirements will according to the interviewees affect the whole value chain for buildings. It is expected to have the most direct impact for the building material producers and especially the building owners who will need to reflect such requirements in the sourcing of building materials and in the design, refurbishment and demolition of buildings.

The underlying assumption is that the building owner and developers who finance the building set the criteria for the design and demolition of buildings. They hereby have a key role in initiating a transition toward a more circular economy in the building and construction sector.

The interviewees expect that the three main summarised groups of policy instruments can accelerate the transition toward a circular economy in the construction sector. The reason is that the interviewees expect that the requirements will create a market pull when the building owners starts sourcing product and services that improves the recyclability and reuse of building materials.

Across the suggested policy instruments, the 16 interviewees find that a transition toward a more circular economy in the construction sector will have great positive environmental impact, a neutral impact for the economy of public authorities and a positive impact on the economy of private companies.

To support the implementation of policy instruments that can accelerate a transition toward a circular economy in the Nordic construction sector COWI recommends The Environment and Economic Group (MEG) under the Nordic Council of Ministers (NCM) and Nordic Waste Group (NAG) to:

- Analyse how the suggested policy instruments apply to the legislative structure and policies of Denmark, Finland, Norway and Sweden, respectively. This includes prioritising the suggested policy instruments most effective and suitable for implementation in each country.

- Develop a socio-economic impact analysis of the suggested policy instruments by collecting and analysing national specific data. It is recommended to involve key stakeholders from the value chain for input and validation. 
- Investigate the definitions of recycled and reused materials from the construction sector to ensure that the assessments are performed on the same assumptions and decisions within and also among each of the Nordic countries.

- Collect information about supplementary environmental impact categories such as embodied energy, use of scarce and renewable resources, acidification etc. to ensure an environmental impact assessment based on a more holistic approach.

- Collect and disseminate information and data on best-case examples of value chain collaboration and quality assurance mechanisms as inspiration for the Nordic construction sector and policy makers.

- Design national roadmaps by inviting large private and public builders owners to workshops and/or dialogues about the benefits and barriers for a transition toward a circular economy, including the most needed actions to succeed. NAG or MEG can facilitate the workshops and share key findings.

- Facilitate increased collaboration between the Nordic countries to realize the expected positive gains from the circular economy transition. Examples are cross-cycle and cross-sector collaboration which can be improved among industries. Other examples are increased collaboration between national policy makers with the aim of decreasing transactional costs, leverage potential complementarities etc. 



\section{Activities, process and methodology}

The project activities and applied process are described in the following sections.

\subsection{Brief literature review}

To extract knowledge from the most relevant studies on circular economy and associated information about policy instruments and barriers this first step focus on the latest and most sound analyses of circular economy in a building context in "The opportunities of a circular economy for Finland"(SITRA), "Potential for Denmark as a circular economy"and "Delivering the circular economy. A toolkit for policy makers"(Ellen MacArthur Foundation) and lastly experiences from WRAP (Waste and Resources Action Programme in England).

The knowledge from the brief literature review has been used as background knowledge by COWI and SYKE during the interviews. The data in the chosen literature have not been applied directly for the assessment of impacts.

\subsection{Interviews}

Sixteen interviews have been conducted with selected interviewees. Four interviews in Denmark, Finland, Norway and Finland, respectively. We have selected interviewees with an outstanding insight in both circular economy and the market drivers of the construction sector. In most of the Nordic countries these specialist are employed at universities, public authorities and industry organisations. Another benefit of inviting those to participate in interview is that they also have insight in the policy making and various policy instrument that can be used to develop a more circular economy.

Each stakeholder received an interview guide before the interviews were conducted. A national expert from COWI Sweden, COWI Norway, COWI Denmark and SYKE in Finland conducted the interviews. All national experts from COWI and SYKE have insight in national policy instruments, legislation, resource efficiency and the construction sector in the specific Nordic country.

The interviewees in Denmark, Finland, Norway and Sweden are listed in the tables below (12-15). Organisation and interviewees are highlighted in each of the tables. 


\section{Table 13: Finland}

\section{Organisation}

Finnish Environmental Industries (YTP)

Helsinki Region Environmental Services Authority HSY

Riikka Kinnunen

Confederation of Finnish Construction Industries RT

Nea Metsänranta

Finnish Environment Institute

Table 14: Norway

\begin{tabular}{ll}
\hline Organisation & Interviewee \\
\hline $\begin{array}{l}\text { The Federation of Norwegian Industries } \\
\text { The Federation of Norwegian Construction Industries }\end{array}$ & Gunnar Grini \\
The trade organisation Bygg uten Grenser & Rannveig Ravnanger Landet \\
Norwegian Association of Heavy Equipment Contractors) & Jan Eldegard \\
& Sverre Huuse Fagerlie
\end{tabular}

Table 15: Sweden

\begin{tabular}{ll} 
Organisation & Interviewee \\
\hline & \\
Svensk Byggindustri & Marianne Hedberg \\
The Swedish Recycling Industries' Association & Britt Sahleström \\
Avfall Sverige & Jon Nilsson-Djerf \\
IVL Svenska Miljöinstitutet & Martin Erlandsson
\end{tabular}

\subsection{Applied process}

Condensing and communicating the results of the 16 interviews is structured in a fivestep process:

1. Each interview will condense two policy instruments highlighted by the interviewee. The national interviewees will sum up the results of the interviews in fact sheets (1-2 pages), one for each of the highlighted policy instruments. With four interviews per country and two policy instruments per interview, then there are 8 fact sheets for each country and 32 fact sheets across the four Nordic countries. The data and information will be used as a basis to provide rough estimates of the overall economic and environmental costs, impacts and benefits to the ecosystem services. 
2. The facts sheets are then summed up within waste legislation, transport legislation, environmental legislation, taxation and fees.

3. The findings from the interviews will be summed up in an executive summary, reporting on both the policy instruments, waste fractions and hypotheses.

4. Scoring of the identified policy instruments. This step uses learnings from the previous steps as the basis of the scoring of the identified policy instruments. This means that the scoring of potential policy instruments will be based on the assessed literature, COWI's experience from other studies and lastly the undertaken interviews. A semi quantitative scoring model has been applied. It means that the scoring is based on the interviewees' estimation of an aspect on a scale from -5 to +5 . Where -5 is a very negative effect, o (zero) is a neutral effect and +5 is a very high positive effect. The purpose of the scoring is to enable the development of recommendations.

5. Development of recommendations for the future focus is described. The assessments of impacts and related recommendations are split into two time phases:

- Short run as 2-5 years from implementation of the suggested policy instruments.

- Long run as 5-10 years from implementation of the suggested policy instruments. 



\section{References}

Affaldsstatistik. 2015. Miljø- og Fødevareministeriet. Miljøprojekt nr. 1941. June 2017. Accessed in 2017 via https://www2.mst.dk/Udgiv/publikationer/2017/05/978-87-93614-01-7.pdf

https://www2.mst.dk/Udgiv/publications/2017/08/978-87-93614-20-8.pdf

Avfallsförordning (2011:927). Sveriges Riksdag. Accessed in 2017 via https://www.riksdagen.se/sv/dokument-lagar/dokument/svenskforfattningssamling/avfallsforordning-2011927_sfs-2011-927

Avfallsregnskapet, 2013. Statistisk sentralbyrå. 2015. Accessed via https://www.ssb.no/naturog-miljo/statistikker/avfregno/aar/2015-06-16

Avfall i Sverige 2012. Naturvårdsverket. Report no. 6619. 2014. Accessed via http://www.naturvardsverket.se/Documents/publikationer6400/978-91-620-66192.pdf?pid $=13196$

Avfall fra byggeaktivitet. Statistics sentralbyrå. Accessed via https://www.ssb.no/statistikkbanken/selectvarval/Define. asp? subjectcode=\&Productld=\&Mai nTable=AvfallGenBygg\&nvl=\&PLanguage=o\&nyTmpVar=true\&CMSSubjectArea=natur-ogmiljo\&KortNavnWeb=avfbygganl\&StatVariant=\&checked=true

Avfall i Sverige 2014. Report no. 6727. Naturvårdsverket. 2016

BASTA. Accessed in 2017 via http://www. bastaonline.se/

Byggevarestatistik - import/eksport. Pr. 1. kvartal - 2015. Byggevareindustrien. Accessed in 2017 via

http://www.byggevareindustrien.no/getfile.php/Bilder/Artikkelbilder/Byggevareindustriens\% 2oForening\%20-\%2oimport-\%20eksportstat\%202015-01\%281\%29.pdf

Byggvarubedömningen (BVB), Accessed in 2017 via https://www.byggvarubedomningen.se/

Bygningsmassen 1. januar 2017. Statistisk sentralbyrå. 2017 Accessed in 2017 via https://ssb.no/bygg-bolig-og-eiendom/statistikker/bygningsmasse

Biolntelligence Services et al., December 2015. Construction and Demolition Waste Management in FINLAND $V_{3}$.

Building information modelling. Wikipedia. Accessed in 2017 via https://en.wikipedia.org/wiki/Building_information_modeling

Circular economy. The European Commission. Accessed in 2017 via http://ec. Europa.eu/growth/industry/sustainability/circular-economy/

Construction Products Regulation (CPR). The European Commission. Accessed in 2017 via http://ec.europa.eu/growth/sectors/construction/product-regulation_da

Danmark uden Affald. Guide from the Danish Environmental Protection Agency no. 4. 2014. Accessed via http://mst.dk/media/mst/Attachments/Ressourcestrategi_DK_web.pdf

Danmark uden affald - strategi \& ressourceplan. The Danish Environmental Protection Agency. 2013. Accessed via http://mst.dk/affald-jord/affald/affaldshaandtering-strategiaktiviteter/danmark-uden-affald-strategi-plan/

Debattartikel i Dagens Samhälle: Kommunerna sitter på flera stolar i avfallshanteringen.

Återvinningsindustrierna. 2016. Accessed in 2017 via

http://www.recycling.se/nyheter-media/debattartiklar/okad-konkurrens-pa-avfallsmarknaderbehovs-i-en-cirkular-ekonomi

EPD from Saint-Gobain Gyproc AS for Gyproc ${ }^{\circledR}$ Normal- Standard Plasterboard, 2017

https://www.riksdagen.se/sv/dokument-lagar/dokument/svensk-

forfattningssamling/forordning-2001512-om-deponering-av-avfall_sfs-2001-512

EPD Norway, www.epdnorway.no 
Etappmålen. Naturvårdsverket. Accessed in 2017 via

http://www.naturvardsverket.se/Miljoarbete-i-samhallet/Sveriges-miljomal/Etappmal/

Eurostat, definitions INDIC_SB. Data accessed in 2017 via

http://ec.europa.eu/eurostat/web/structural-business-statistics

GaBi Professional version 6.3. 2017. More information can be retrieved via http://www.gabisoftware.com/databases/professional.

Fakta om avfallsbransjen. LOOP. 2016. Accessed via http://loop.no/statistikk/avfallsbransjen/

Government Decree 591/2006 concerning the recovery of certain wastes in earth construction

Government Decree concerning the recovery of certain soil waste in earth construction (currently being developed)

Kohdennetut keinot kierrätyksen kasvuun. Valtioneuvoston selvitys- ja tutkimustoiminnan julkaisusarja 53/2016. Salmenperä et al. 2016.

Kort sagt om Strategi for affaldsforebyggelse. Danmark uden affald II. The Danish Environmental Protection Agency. 2015. Accessed via http://mst.dk/media/91797/mst_pixi_web_30-11-2015_-2.pdf

Kortlægning af genbrugsmarkeder for byggematerialer. 2014. CLEAN

Liitetaulukko 2. Jätteiden kertymät toimialoittain ja jätelajeittain vuonna 2013The Environmental Ministry report no. 17. 2015. Accessed via http://www.stat.fi/til/jate/2013/jate_2013_2015-05-28_tau_002_fi.html

Material passport. Wikipedia. Accessed in 2017 via https://en.wikipedia.org/wiki/Material_passport

Miljöbalk (1998:808). Sveriges Riksdag. 1998. Accessed in 2017 via https://www.riksdagen.se/sv/dokument-lagar/dokument/svenskforfattningssamling/miljobalk-1998808_sfs-1998-808

Miljødirektoratet (2017). Program for avfallsforebygging (vedlegg til den nasjonale avfallsstrategien). Miljødirektoratet. 2017. Accessed via http://www.miljodirektoratet.no/Global/dokumenter/horinger/Regelverk/Vedlegg\%200m\%20 infrstruktur\%2otil\%2oden\%2onorske\%2oavfallsstrategien.pdf?epslanguage=no

NACE Rev. 2. Statistical classification of economic activities in the European Community. Eurostat. ISSN 1977-0375. Accessed in 2017 via http://ec.

Europa.eu/Eurostat/documents/3859598/5902521/KS-RA-07-015-EN.PDF

Regeringsuppdrag Icke farligt byggnads- och rivningsavfall. Naturvårdsverket. Accessed in 2017 via https://www.regeringen.se/contentassets/c286a4ac8d8042a9826649obc13ddf7d/naturva rdsverkets-redovisning-av-regeringsuppdrag-icke-farligt-byggnads--ochrivningsavfall.pdf

Notisum. Karnov Group. Lag (1999:673) om skatt på avfall. Accessed in 2017 via http://www.notisum.se/rnp/sls/lag/19990673.htm

Omsetning i bygge- og anleggsvirksomhet. Statistisk sentralbyrå. 2016. Accessed via https://www.ssb.no/bygg-bolig-og-eiendom/statistikker/bygganloms (05.05.2017)

Remissvar Boverkets rapport Byggnaders klimatpåverkan utifrån ett livscykelperspektiv. Återvinningsindustrierna. 2016. Accessed in 2017 via http://www.recycling.se/branschfragor/remissvar/remissvar-2016_2/remissvar-boverketsrapport-byggnaders-klimatpaverkan-utifran-ett-livscykelperspektiv

Remissvar Boverkets rapport Dokumentationssystem för byggprodukter vid nybyggnation. Återvinningsindustrierna. 2016. Accessed in 2017 via http://www.recycling.se/branschfragor/remissvar/remissvar-2016_2/remiss-boverketsrapport-dokumentationssystem-for-byggprodukter-vid-nybyggnation

Resurs- och avfallhantering vid byggande och rivning. 2016 Accessed via https://www.sverigesbyggindustrier.se/resurs-och-avfallshantering-vid-byggand_6595

Structural Business Statistics \& Global Business Activities. Eurostat. The European Commission. Accessed in 2017 via http://ec.europa.eu/eurostat/web/structural-business-statistics 
Towards a circular economy, The European Commission. Accessed in 2017 via https://ec.Europa.eu/commission/priorities/jobs-growth-and-investment/towards-circulareconomy_en

Towards a recycling society - The National Waste Plan for 2016, Ministry of the Environment. 2016. Accessed via

https://helda.helsinki.fi/bitstream/handle/10138/38022/FE_14_2009.pdf?sequence=1

Trucost's valuation methodology. Thinkstep. May 2015. Accessed via http://www.gabisoftware.com/fileadmin/GaBi_Databases/Thinkstep_Trucost_NCA_factors_methodology_rep ort.pdf

Sundahus. Accessed in 2017 via https://www.sundahus.se/

Sweden Green Building Council. Accessed in 2017 via https://www.sgbc.se/varverksamhet/miljoebyggnad

Uppföljning av etappmålen. Miljömålen - årlig uppföljning af Sveriges miljömålskvalitetsmål och etappmål, 2016 2016. Accessed via https://www.miljomal.se/Global/24_las_mer/rapporter/malansvariga_myndigheter/2016/etap pmalen-2016.pdf

Utslipp av klimagasser, 1990-2015, final data. Statistisk sentralbyrå. 2016. Accessed via https://www.ssb.no/natur-og-miljo/statistikker/klimagassn/aar-endelige/2016-1213 ?fane=tabell \&sort=nummer \&tabell $=287205$

What is an EPD? The International EDP System. Accessed in 2017 via http://www.environdec.com/en/What-is-an-EPD/

Wikipedia. Accessed in 2017 via https://da.wikipedia.org/wiki/BIM

$\varnothing$ kt omsetning for bygg og anlegg i 2016. Statistisk sentralbyrå. 2016. Accessed via https://www.ssb.no/bygg-bolig-og-eiendom/artikler-og-publikasjoner/okt-omsetning-forbygg-og-anlegg-i-2016 (05.05.2017)

\section{Names / organisations of interviewees and the interview dates}

The Danish Environmental Protection Agency: Niels Bukholt. Interviewed at April 7, 2017.

Danish Waste Association: Jacob Hartvig Simonsen. Interviewed at March 29, 2017.

The Centre for Management and Recycling of Construction Waste: Anke Oberender. Interviewed at March 29, 2017.

Confederation of Danish Industry: Elly Kjems Hove and Jakob Orbesen. Interviewed at April 20, 2017.

Finnish Environmental Industries: Riikka Kinnunen. Interviewed at April 19, 2017.

Helsinki Region Environmental Services Authority: Nea Metsänranta. Interviewed at April 18, 2017.

Confederation of Finnish Construction Industries: Pekka Vuorinen. Interviewed at April 6, 2017.

Finnish Environmental Institute: Petrus Kautto. Interviewed at April 19, 2017.

The Federation of Norwegian Industries: Gunnar Grini. Interviewed at April 21, 2017.

The Federation of Norwegian Construction Industries: Rannveig Ravnanger Landet. Interviewed at April 19, 2017.

Bygg uten Grenser: Jan Eldegaard. Interviewed at April 20, 2017

Norwegian Association of Heavy Equipment Contractors: Sverre Huuse Fagerlie. Interviewed at April 24, 2017.

The Swedish Construction Federation: Marianne Hedberg. Interviewed at April 7, 2017.

The Swedish Recycling Industries' Association: Britt Sahleström. Interviewed at May 11, 2017.

Avfall Sverige: Jon Nilsson-Djerf. Interviewed at April 25, 2017.

IVL Svenska Miljöinstitutet: Martin Erlandsson. Interviewed at May 5, 2017. 



\section{Sammenfatning}

Formålet med dette projekt er at identificere og diskutere hvilke policy instrumenter, der kan accelerere en omstilling til en cirkulær økonomi i den nordiske byggesektor. ${ }^{61}$ Seksten interviews er blevet gennemført med interessenter fra Danmark, Finland, Norge og Sverige.

Målet med en omstilling til øget cirkulær økonomi er at vedligeholde, genbruge, renovere og genanvende byggevarer, som bliver anvendt i alle dele af værdikæden.

De nordiske interessenter foreslår særligt at fokusere på regler og regulering. Kun få fokuserer på økonomiske incitamenter, frivillige aftaler eller information. De regler og den regulering, som interessenterne foreslår, fokuserer produktdesign og særligt på bygningsdesign og nedrivning af bygninger.

De policy instrumenter, som flest interessenter foreslår, fokuserer sammenfattende på tre hovedtyper af policy instrumenter:

1. Supplerende krav til dokumentation af byggevarernes indhold og kvalitet.

2. Nye krav til dokumentation af genbrug af byggevarer samt brug af byggevarer indeholdende genanvendte ressourcer i bygninger.

3. Nye krav til nedrivnings- og affaldsplaner.

Disse politiske instrumenter vil kræve øget dokumentation af byggevarernes tekniske specifikationer (herunder kvalitet, levetid, styrke, indhold af miljøfremmede stoffer osv.), forbedrede muligheder for sporbarhed $\mathrm{i}$ forhold til indholdsstoffer samt minimumskrav til genanvendelse af ressourcer og genbrug af byggevarer:

- Policy instrumenterne vil ifølge de nordiske interessenter påvirke hele værdikæden for byggeri. Særligt vil byggevareproducenter og bygningsejerne blive påvirket heraf i form af krav til implementering af sådanne specifikationer ved køb af materialer og byggevarer i design- genanvendelse- og nedrivningsfaserne.

- De nordiske interessenter foreslår primært forankring af kravene i bygningsreglementerne i Danmark, Finland, Norge og Sverige og derefter i:

- Miljøvaredeklarationer (også kaldet Environmental Product Declarations (EPD)).

- Byggevareforordningen (Construction Products Regulation (CPR)).

- Building Information Modelling System (BIM).

${ }^{61}$ Inklusive nedrivning af bygninger. 
- Materialepas og/eller bygningspas.

De nordiske interessenter vurderer, at de udvalgte policy instrumenter vil skabe store miljømæssige gevinster, at de ikke vil påvirke de offentlige myndigheders budgetter og at de vil skabe økonomisk gevinster for de private virksomheder.

Disse forventede gevinster er også gældende for de tre hovedtyper af policy instrumenter (se ovenfor).

De fleste nordiske interessenter forventer, at virksomhederne $i$ en implementeringsfase skal tilpasse sig til de nye regler og ny regulering. Dette kan medvirke til øgede omkostninger for virksomhederne på kort sigt, men på lang sigt forventer interessenterne, at gevinsterne vil være betydeligt positive - særligt for reduktionen i miljøpåvirkningen.

Ifølge de nordiske interessenter skyldes de forventede gevinster hovedsageligt besparelser af ressourcer, når byggevarer genbruges og ressourcer genanvendes. På lang sigt forventer interessenterne, at gevinsterne opvejer den negative påvirkning, som kan opstå i en implementeringsfase som følge af et eventuelt øget behov for logistik, opbevaring og transport forbundet med genbrug eller genanvendelse af byggevarer.

De nordiske interessenter vurderer, at ressourceforbruget kan reduceres med $20 \%$ sammenlignet med det nuværende forbrug af ressourcer $\mathrm{i}$ byggesektoren.

Ved en reduktion af ressourceforbruget på $20 \%$ vil udledningen af drivhusgasser falde med ca. 10 mio. tons samlet set for alle fire nordiske lande i alle dele af værdikæden fra udvinding af råmaterialer til fremstilling og bortskaffelse inkl. transport.

De budgetmæssige konsekvenser for offentlige myndigheder er ikke vurderet, da de nordiske interessenter anser dem for at være neutrale, hvilket betyder, at de administrative omkostninger og forventede ændringer i skatteindtægter anses for at være ubetydelige - både på kort og på lang sigt.

De økonomiske konsekvenser for private virksomheder vurderes som positive af de nordiske interessenter. En årlig vækst i virksomhedernes i bruttoavance på 1,7\% vil på lang sigt svarer til en nutidsværdi (2018) på 803 millioner EUR i det første år (2023) efter en fuld implementering af de policy instrumenter, som de nordiske interessenter foreslår.

Implementeringen af de i alt 32 policy instrumenter, som de 16 nordiske interessenter foreslår, vil forventeligt accelerere omstillingen til en cirkulær økonomi i den nordiske byggesektor. Men implementeringen af policy instrumenterne kan blive kompliceret, og implementeringsprocessen er nødt til at adressere et antal barrierer, som kan hindre en reduktion i forbrug af ressourcer, emission af drivhusgasser samt den fulde vækst i virksomhedernes bruttoavancer.

Ifølge COWI er de største barrierer er den nuværende:

- Mangel på (tidligt) samarbejde mellem alle parter i værdikæden og dannelse af partnerskaber i byggesektoren.

- Mangel på stordriftsfordele. 
- Mangel på kvalitetssikring og -mærkning af genbrugte byggevarer.

- Indhold af farlige stoffer i de byggevarer, der er i eksisterende bygninger.

COWI forventer, at nye regler og regulativer ikke kan stå alene - hverken til at håndtere barriererne, der er nævnt ovenfor - eller som de eneste politiske instrumenter til at fremskynde en omstilling til en cirkulær økonomi i den nordiske byggesektor.

COWI forventer, at virksomhederne har behov for stærke økonomiske incitamenter for at ændre deres eksisterende og ofte lineære forretningstilgang. Nye beskatningsstrukturer, gebyrer og økonomisk støtte gennem offentlige programmer kan skabe sådanne incitamenter.

Nye beskatningsstrukturer og gebyrer vil sænke prisen på genbrugte byggevarer og genanvendte ressourcer samt øge efterspørgslen. En anden beskatningsstruktur og gebyrer på specifikke byggevarer og ressourcer kan dog blive kompliceret at udvikle og håndhæve.

Herudover vil et differentieret beskatningssystem på byggevarer føre til en lavere skatteindtægt, som vil stige i takt med at efterspørgslen på genbrugte og genanvendte materialer stiger. Omkostningerne forbundet med en ny beskatningsstruktur og gebyrer skal derfor være tidsbegrænsede og fases ud, når markedet for genbrugte byggevarer og byggevarer indeholdende genanvendte ressourcer vækster og bliver effektivt og konkurrencedygtigt $\mathrm{i}$ forhold til byggevarer produceret af primære ressourcer.

Hvis det er tilfældet, kan en kombination af nye regler, regulativer og stærkere $ø$ øonomiske incitamenter give de offentlige myndigheder en nøglerolle i en omstilling til en cirkulær økonomi i byggesektoren. De offentlige myndigheder kan dermed skabe en stor efterspørgsel på bygningsdesign baseret på cirkulære forretningstilgange samt bidrage til facilitering af nødvendige dialoger, partnerskaber og processer.

\section{Anbefalinger}

For at styrke implementeringen af de policy instrumenter, som kan accelerere en omstilling til en cirkulær økonomi i den nordiske byggesektor, anbefaler COWI Miljøøkonomigruppen (MEG) og Nordisk Affaldsgruppe (NAG), at:

- Analysere, hvordan de foreslåede policy instrumenter kan anvendes i den lovmæssige struktur og i politikker i henholdsvis Danmark, Finland, Norge og Sverige. Dette omfatter prioritering af, hvilke af de foreslåede politiske instrumenter, som er bedst egnede til implementering i hvert land.

- Udvikle en socioøkonomisk påvirkningsanalyse ved at indsamle og analysere nationale data og inkludere nøgleinteressenter fra værdikæden med henblik på input og validering. 
- Undersøge definitionerne af genbrugte og genanvendte ressourcer fra byggesektoren for at sikre, at vurderingerne bliver udført ud fra de samme antagelser og beslutninger indenfor og også blandt hvert de nordiske lande.

- Indsamle information om supplerende miljømæssige påvirkningskategorier som f.eks. indlejret energi, anvendelse af vedvarende ressourcer, eutrofiering osv. for at sikre en miljømæssig påvirkningsvurdering, som er baseret på en mere holistisk tilgang.

- Indsamle information og data om best-case eksempler på værdikædesamarbejde og kvalitetssikringsmekanismer som inspiration for den nordiske byggesektor og politikudviklere.

- Udvikle nationale roadmaps ved at invitere store private og offentlige bygherrer til workshops og dialog om fordelene og barriererne forbundet med en omstilling til en cirkulær økonomi inklusive de mest påkrævede aktioner for en succesfuld transition. NAG og MEG kan facilitere sådanne workshops og dele de vigtigste resultater.

- Facilitere et øget samarbejde mellem de nordiske lande for at realisere de forventede positive gevinster fra en omstilling til en cirkulær økonomi. Eksempler er øget og forbedret samarbejde mellem industrier på tværs af livscyklusfaser og interessenter i hele værdikæden. Et andet eksempel er øget samarbejde mellem politikudviklere med formål om at mindske transaktionsomkostninger og udnytte potentielle fælles styrker etc. 
Nordic Council of Ministers

Nordens Hus

Ved Stranden 18

DK-1061 Copenhagen K

www.norden.org

\section{CIRCULAR ECONOMY IN THE NORDIC CONSTRUCTION SECTOR}

Potential policy instruments that can accelerate a transition toward a circular economy in the Nordic construction sector, including demolition of buildings, are discussed and assessed. Sixteen interviews were carried out with actors representing stakeholders from Denmark, Finland, Norway and Sweden.

Implementation of the 32 policy instruments that the 16 interviewees suggest is expected to speed up the transition toward a circular economy. But the implementation of the policy instruments can be complicated and the implementation process needs to address a number of barriers that may hinder a reduction in the use of resources, greenhouse gas emissions and a full growth in gross profit. 